\title{
Giant Sticks from Vietnam and China, with three new taxa including the second longest insect known to date (Phasmatodea, Phasmatidae, Clitumninae, Pharnaciini)
}

\author{
Joachim BRESSEEL ${ }^{1}$ \& Jérôme CONSTANT ${ }^{2}$ \\ 1,2 Royal Belgian Institute of Natural Sciences, D.O. Phylogeny and Taxonomy, Entomology, \\ Vautier Street 29, B-1000 Brussels, Belgium \\ ${ }^{1}$ Email: joachimbresseel@gmail.com (corresponding author) \\ ${ }^{2}$ Email: jerome.constant@naturalsciences.be \\ ${ }^{1}$ urn:1sid:zoobank.org:author:3C4EF358-9716-46F0-8575-26BE1EDE4349 \\ ${ }^{2}$ urn:lsid:zoobank.org:author:6E6072A1-9415-4C8D-8E60-2504444DB290
}

\begin{abstract}
Two new species and one subspecies of Pharnaciini, belonging to two different genera, are described from Vietnam: one species and subspecies of Phryganistria Stål, 1875 and one species of Phobaeticus Brunner von Wattenwyl, 1907. Two species currently attributed to the genus Ramulus Saussure, 1862, Ramulus magnus (Brunner von Wattenwyl, 1907) and R. chinensis (Brunner von Wattenwyl, 1907), are transferred to Baculonistria Hennemann \& Conle, 2008 comb. nov. Phobaeticus longicornis Bi \& Wang, 1998 and Phobaeticus yuexiensis Chen \& He, 1993 represent the male and female of Baculonistria magnus (Brunner von Wattenwyl, 1907) syn. nov. A lectotype is designated for Baculonistria chinensis (Brunner von Wattenwyl, 1907). The genus Baculonistria now contains three species. Nearchus bachmaensis Ta \& Hoang, 2004 is transferred to Phryganistria and the new combination Phryganistria bachmaensis (Ta \& Hoang, 2004) comb. nov. is proposed. The species is redescribed and the authors' attribution corrected, the egg is described and figured for the first time. Phryganistria tamdaoensis sp. nov. is described and figured from both sexes and the egg. Females of $P$. tamdaoensis sp. nov. are easily recognised by the conspicuously enlarged lanceolate cerci, a character previously unknown in this tribe. The distribution range of Phryganistria heusii heusii (Hennemann \& Conle, 1997) is extended to Tam Dao National Park. A new subspecies Phryganistria heusii yentuensis subsp. nov. is described from Tay Yen Tu Nature Reserve from adult males and females and the eggs. Males can easily be distinguished from the nominal subspecies by their colouration. This huge subspecies represents the second longest insect recorded to date. A key to the species of the genus Phryganistria is provided. Phobaeticus trui sp. nov. is described from central Vietnam. It is the first species of Phobaeticus recorded from Vietnam. Adults of both sexes are illustrated.
\end{abstract}

Key words. Phryganistria, Phobaeticus, Baculonistria, walking sticks, South-East Asia

Bresseel J. \& Constant J. 2014. Giant Sticks from Vietnam and China, with three new taxa including the second longest insect known to date (Phasmatodea, Phasmatidae, Clitumninae, Pharnaciini). European Journal of Taxonomy 104: 1-38. http://dx.doi.org/10.5852/ejt.2014.104 


\section{Introduction}

The tribe Pharnaciini Günther, 1953 is well known for its so called giant stick insects and includes the longest insects in the world. Although forty-four species have previously been described, many were described relatively recently (Brock 1998; Zompro 2005; Hennemann \& Conle 1997, 2008; Bragg 1995, 2008; Chen \& He 2008), which indicates that even more of these giant species await description.

In a recent revision of the tribe Pharnaciini, Hennemann \& Conle (2008) removed the tribe from Phasmatinae and transferred it to the re-established subfamily Clitumninae Brunner v. Wattenwyl, 1907. Currently five genera, forty-six species and one subspecies are attributed to the tribe. Former authors were unaware of Nearchus bachmaensis Ta \& Hoang, 2004, a species described in Vietnamese, here redescribed in English and attributed to Phryganistria Stål, 1875.

Several expeditions to Vietnam and extensive field collecting have revealed other undescribed taxa belonging to the tribe, doubling the number of species known from the country: Phryganistria tamdaoensis sp. nov. from north and central Vietnam, and Phobaeticus trui sp. nov. from central Vietnam and Phryganistria heusii yentuensis subsp. nov. from northeast Vietnam. P. heusii yentuensis subsp. nov. is the second longest insect known to date: a female with a $32 \mathrm{~cm}$ body length, $54 \mathrm{~cm}$ with anterior legs spread, was captured in the field.

The genus Baculonistria Hennemann \& Conle, 2008 is currently recorded only from China and remains problematic as several species are attributed to Ramulus Saussure, 1862 and examination of type specimens is necessary. Two species described by Brunner von Wattenwyl (1907) are here transferred to Baculonistria Hennemann \& Conle, 2008, one of which has furthermore also been described two times under synonymic names. The genus Ramulus Saussure, 1862 appears to be heterogeneous as it appears to contain several distinct generic units. However, extensive research is necessary to decide on the generic placement of species currently referred to Ramulus Saussure, 1862. Hopefully future availability of type specimens will result in the correct generic placement of these species.

\section{Material and methods}

The definition of the genera follows Hennemann \& Conle (2008) and all the keys to the species presented below are adapted from this same monograph.

Due to their nocturnal behaviour, most specimens studied herein were collected at night. A light-weight and water-proof Petzl MYO RXP head torch was used during collecting. Females were kept alive in a mesh pop up cage (Exo Terra Explorarium ${ }^{\circledR}$ ) for producing eggs. During daytime, branches of larger trees next to the trail or road were beaten with a telescopic net handle $(4.5 \mathrm{~m})$ and several specimens were collected after having fallen down. Eggs were then cultured in captivity, a good way to observe behaviour, younger instars and intraspecific variation.

Specimens caught in the wild were euthanized by a lethal injection with ethanol. Due to their size and tendency to lose legs, Pharnaciini specimens are rolled in paper with the legs secured close to the body. Once fixed in paper, specimens were then stored in airtight plastic "zip"-bags in wood chips (used in rodent cages) and sprinkled with ethylacetate (EtOAc) to prevent rotting, mould and to keep the specimens flexible. The bags were then frozen on arrival and the specimens were mounted later on. For all new taxa described, the description of the colours is based on photographs of living specimens.

\section{Acronyms used for the collections}

IEBR = Institute of Ecology \& Biological Resources, Vietnamese Academy of Sciences, Hanoi, Vietnam 
BRESSEEL J. \& CONSTANT J., Pharnaciini from China and Vietnam (Phasmatodea: Phasmatidae)

IZCAS = Institute of Zoology, Chinese Academy of Sciences, Beijing, China

MNHN $=$ Museum National d'Histoire Naturelle, Paris, France

NHMW $=$ Naturhistorisches Museum Wien, Wien, Austria

RBINS = Royal Belgian Institute of Natural Sciences, Brussels, Belgium

VNMN = Vietnam National Museum of Nature, Vietnamese Academy of Sciences, Hanoi, Vietnam

ZIN = Russian Academy of Sciences, Zoological Institute, St. Petersburg, Russia

\section{Results}

\section{Taxonomy}

Family Phasmatidae Gray, 1835

Subfamily Clitumninae Brunner von Wattenwyl, 1893

We follow the definition of the subfamily proposed by Hennemann \& Conle 2008, except for the characters of the cerci. The discovery of a species of Phryganistria showing large cerci leads us to extend the definition to species with prominently enlarged and lanceolate cerci.

Tribe Pharnaciini Günther, 1953

Baculonistria Hennemann \& Conle, 2008

Baculonistria Hennemann \& Conle, 2008: 85.

\section{Type species}

Baculum album Chen \& He, 1990: 54, figs 1a-c, by original designation.

\section{Distribution}

Central \& eastern China (Hennemann \& Conle 2008).

\section{Species included}

1. Baculonistria alba (Chen \& He, 1990): 54, figs. 1a-c. [China (Sichuan \& Chongqing)] syn. Phobaeticus sichuanensis Cai \& Liu, 1993: 469.

2. Baculonistria chinensis (Brunner von Wattenwyl, 1907): 202 comb. nov. [China (Sichuan)]

3. Baculonistria magna (Brunner von Wattenwyl, 1907): 236 comb. nov. [China (Shanghai, Henan Prov. Anhui Prov.)]

syn. Phobaeticus longicornis Bi \& Wang, 1998: 10, figs. 5-6 syn. nov.

syn. Phobaeticus yuexiensis Chen \& He, 1993: 54, figs. 1-2 syn. nov.

\section{Keys to the species of Baculonistria}

\section{Females}

1. Subgenital plate short, not reaching apex of anal segment; East China

- Subgenital plate long and lanceolate, prominently projecting over apex of anal segment; central China B. alba (Chen \& $\mathrm{He}, 1990)$

2. Cerci lanceolate and flattened, distinctly projecting over apex of abdomen.....

B. magna (Brunner von Wattenwyl, 1907)

- Cerci not lanceolate, not projecting over apex of abdomen.

B. chinensis (Brunner von Wattenwyl, 1907) 
Males

1. Genae white, legs brown; mesofemora serrated ventrally

- Head and legs green and glabrous; meso- and metafemora unarmed

B. chinensis (Brunner von Wattenwyl, 1907)

2. Antennae with 15 segments; femora with a longitudinal row of pale elliptical spots laterally; meso- and metafemora without a distinct sub-apical spine ventrally; East China

B. magna (Brunner von Wattenwyl, 1907)

- Antennae with 25 segments; femora without lateral spots; meso- and metafemora with a distinct, sub-apical spine on medioventral carina; central China

B. alba (Chen \& He, 1990)

Baculonistria chinensis (Brunner von Wattenwyl, 1907) comb. nov.

Fig. $1 \mathrm{~A}-\mathrm{J}$

Cuniculina chinensis Brunner von Wattenwyl, 1907: 202.

Baculum chinensis - Bi, Chen \& He in Huang, 1992: 68 — Brock 1998: 21.

Ramulus chinensis - Otte \& Brock, 2005: 301. — Brock \& Delfosse 2005: 51. — Brock 2007: 49. Hennemann, Conle \& Zhang 2008: 28.

Baculum chinense - Chen \& He, 2008: 295.

\section{Type material examined}

Lectotype (by present designation), ふ̋: Coll. Br. v. W., Sichuan, Fubyankho, Shintian- Lamasy, 2.VIII. [18]93, Potanin leg. (translated from Russian by Dr Vladimir Gnezdilov); det. Br. v. W. (NHMW);

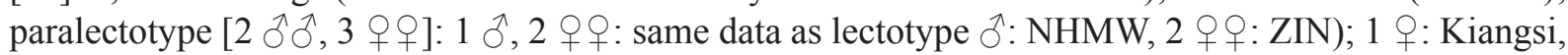
A. David $1875(\mathrm{MNHN})$.

\section{Note}

One male labelled "China Southeast, Chang Hai" in MNHN bears a type label. This specimen is here not recognized as a type because Brunner von Wattenwyl (1907) only mentions Kiangsi for the material in MNHN. Furthermore, examination has shown the specimen to be a male of B. magna (Brunner von Wattenwyl, 1907).

\section{Remarks}

When Brunner von Wattenwyl (1907) described Cuniculina chinensis, he stated that there was a large series of specimens "characterised by their variation". At the moment only five specimens are traced: 2 males in NHMW, 2 females in ZIN and one female in MNHN.

Unfortunately the material in ZIN and NHMW is strongly damaged. A male syntype in NHMW is designated as lectotype. The other male lacks part of the abdomen. The female deposited in MNHN is from a different locality than the other types. The locality on the label mentions Kiangsi which is an old name for current Jiangxi Province, located in southeast China. This locality is relatively remote from Sichuan where the other material originates from.

Since the shape and size of the cephalic spines and armature of the legs is fairly different from the other specimens it remains questionable if the male and female are conspecific. 


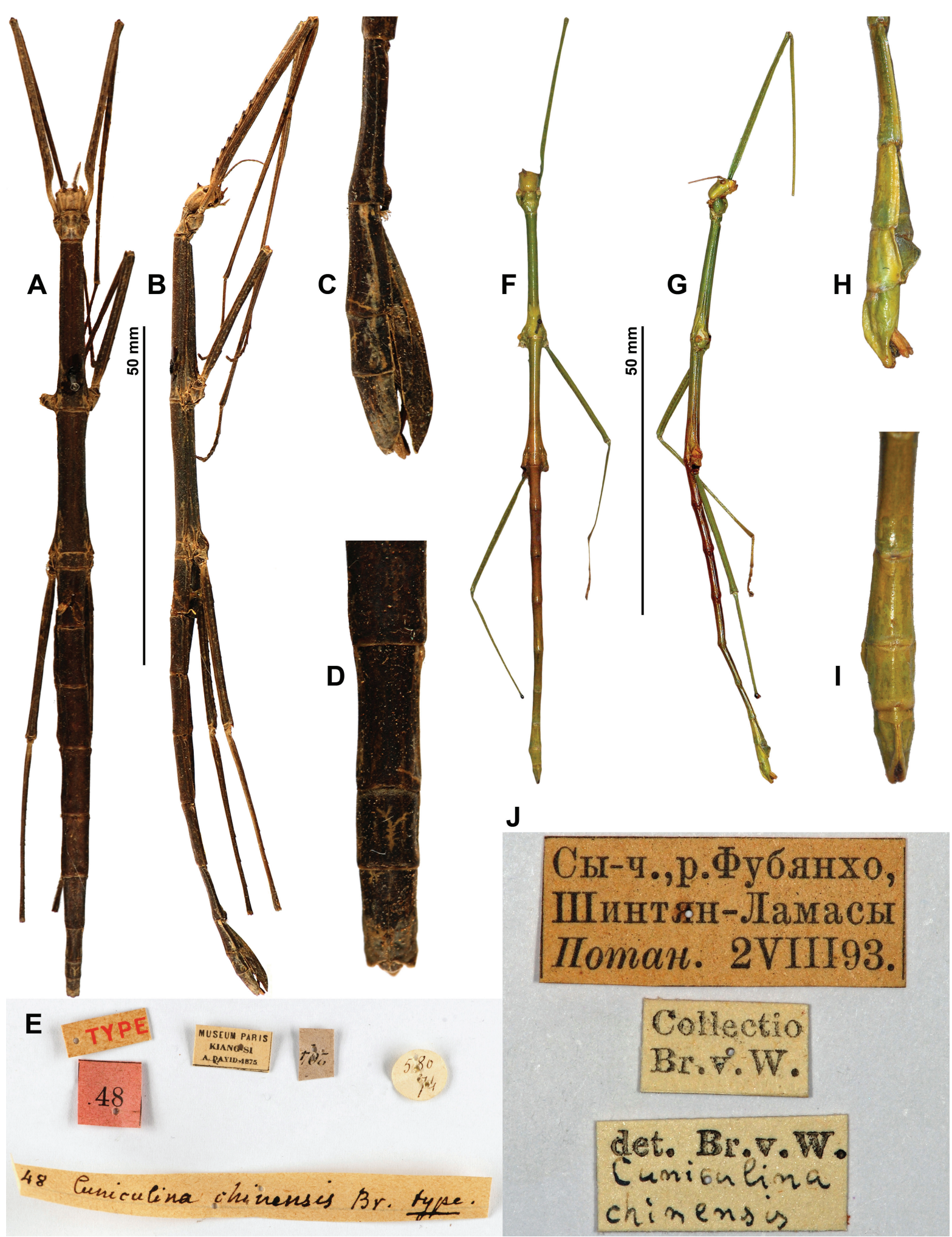

Fig. 1. Baculonistria chinensis (Brunner von Wattenwyl, 1907). - A-E. Paralectotype $q$ (MNHN, photographs by Emmanuel Delfosse). A. Habitus, dorsal view. B. Habitus, lateral view. C. Apex of abdomen, lateral view. D. Apex of abdomen, dorsal view. E. Labels. - F-J.Lectotype $\widehat{\sigma}$ (CNatural History Museum Vienna, Orthoptera Image Collection, published with permission). F. Habitus, dorsal view. G. Habitus, lateral view. H. Apex of abdomen, lateral view. I. Apex of abdomen, dorsal view. J. Labels. C-D, H-I = not to scale. 
Baculonistria magna (Brunner von Wattenwyl, 1907) comb. nov.

Fig. 2 A-J

Clitarchus magnus Brunner von Wattenwyl, 1907: 236.

Phobaeticus yuexiensis Chen \& He, 1993: 54, figs 1-2 syn. nov.

Phobaeticus longicornis Bi \& Wang in Shen \& Shi, 1998: 9, figs 5-6 syn. nov.

Clitarchus magnus - Otte \& Brock 2005: 97. — Brock \& Delfosse 2005: 54. - Hennemann, Conle \& Zhang 2008: 43. - Chen \& He 2008: 343.

Phobaeticus longicornis - Otte \& Brock 2005: 269. — Hennemann, Conle \& Zhang 2008: 9.

Phobaeticus yuexiensis - Hennemann, Conle \& Zhang 2008: 9.

Baculum yuexiense - Chen \& He 2008: 290, fig. 256.

Baculum longicornis - Chen \& He 2008: 255, fig. 216.

Baculonistria yuexiensis - Hennemann \& Conle 2008: 92.

Baculonistria longicornis - Hennemann \& Conle 2008: 91.

\section{Type material examined}

Holotype, $q$ (examined on photographs): Chang Hai, P. Joannis, 96 (MNHN).

\section{Additional material examined}

$1 \hat{\delta}$ (examined on photographs): same data as holotype (MNHN). Identified as Clitumnus chinensis Brunner von Wattenwyl, 1907, see note supra.

\section{Remarks}

Brunner von Wattenwyl (1907) described Clitarchus magnus based on a single female. He attributed this species to the genus Clitarchus Stål, 1875, a genus endemic to New Zealand, because of the lanceolate and flattened cerci. This character was previously unknown within the Pharnaciini, but is also present in the newly described Phryganistria tamdaoensis sp. nov.

The male specimen, although bearing the same data as the female, was not recognised as the same species by Brunner von Wattenwyl. Instead, the male specimen is in the type series of Baculonistria chinensis comb. nov. and can easily be distinguished from the male specimens of that species deposited in NHMW.

The labels on the male and female clearly state Chang Hai (now Shanghai) in eastern China. They were misread by Brock \& Delfosse (2005) as Chiang Mai (Thailand). The labels also mention Joannis, the collector of the specimens, who published several entomological papers on species from China.

Following the translations of the original descriptions provided by Hennemann (2008), it appears that Phobaeticus longicornis Bi \& Wang, 1998 represents the male of Baculonistria magna and that Phobaeticus yuexiensis Chen \& He, 1993 is the female of the same species. The type localities of $P$. longicornis Bi \& Wang, 1998 and P. yuexiensis Chen \& He, 1993 are also in eastern China (Henan Province and Anhui Province, respectively) and relatively close to Shanghai (Fig. 12D). Consequently, both species are here synonymised with Clitarchus magnus Brunner von Wattenwyl, 1907 (syn. nov.). 

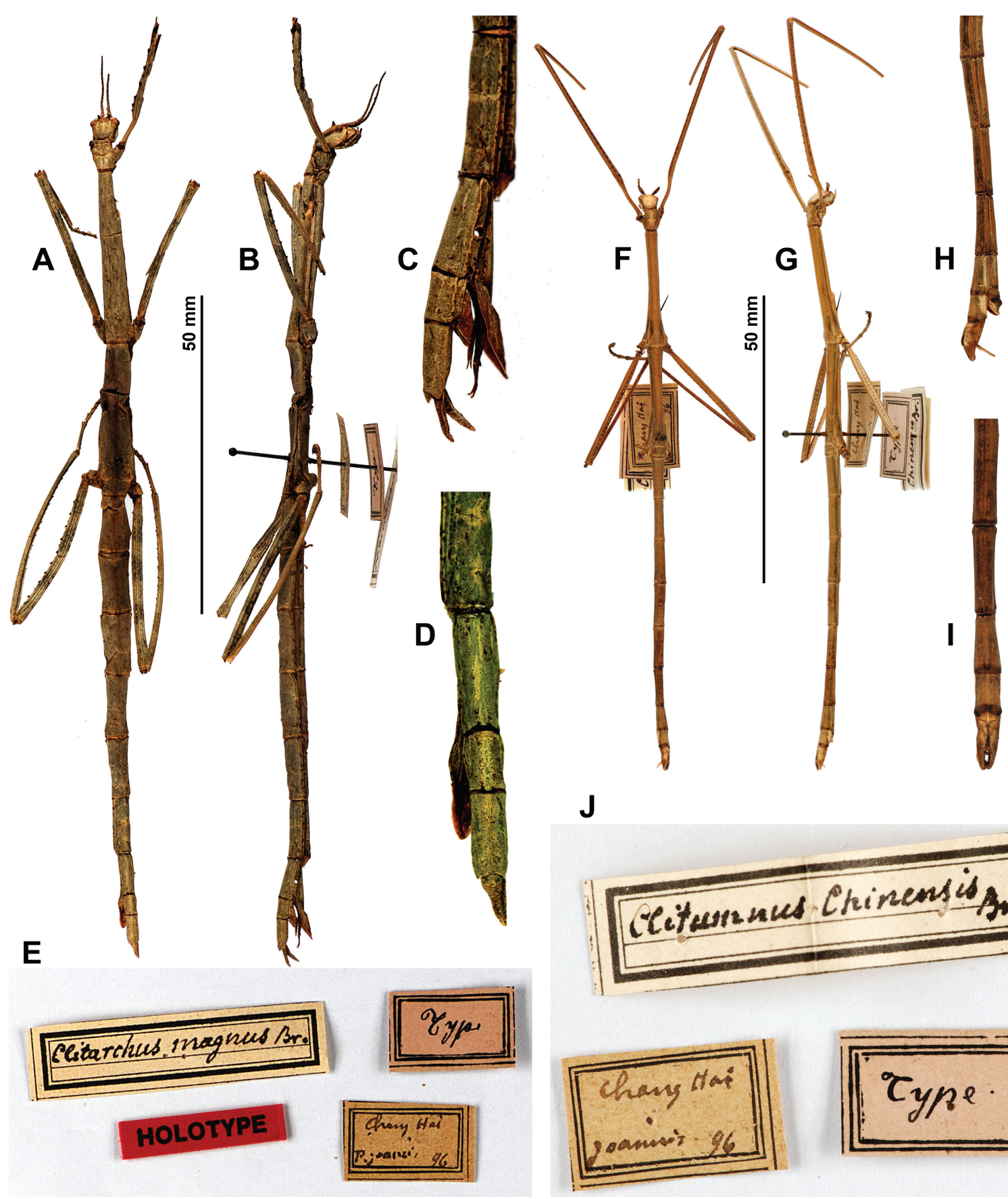

$\mathbf{J}$
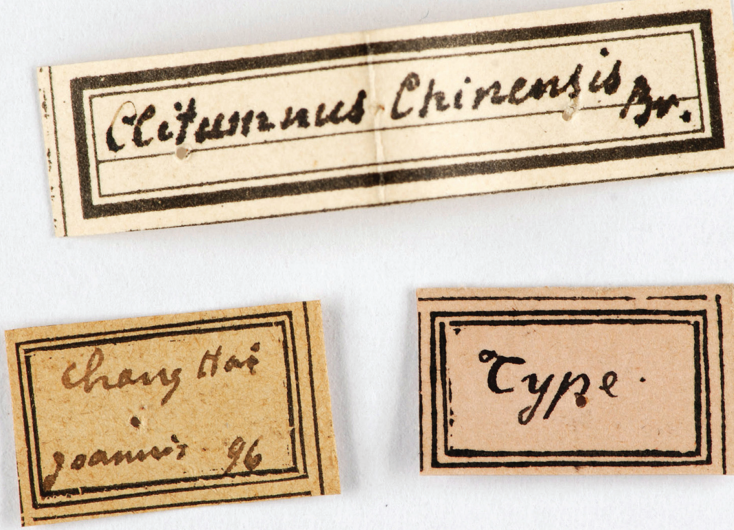

cype.

Fig. 2. Baculonistria magna comb. nov. (Brunner von Wattenwyl, 1907). - A-E.Holotype $q$ (MNHN, photographs by Emmanuel Delfosse). A. Habitus, dorsal view. B. Habitus, lateral view. C. Apex of abdomen, lateral view. D. Apex of abdomen, dorsal view. E. Labels. - F-J. $\widehat{\partial}$ (MNHN, photographs by Emmanuel Delfosse). F. Habitus, dorsal view. G. Habitus, lateral view. H. Apex of abdomen, lateral view. I. Apex of abdomen, dorsal view. J. Labels. C-D, H-I = not to scale. 


\section{Phryganistria Stål, 1875}

Phryganistria Stål, 1875:14.

\section{Type species}

Bacteria sarmentosa Westwood, 1848: 66, pl. 32, figs 1-2 (= Bacteria virgea Westwood, 1848: 66), by subsequent designation by Kirby, 1904: 358 .

\section{Subspecies and species included}

1. Phryganistria bachmaensis (Ta \& Hoang, 2004) comb. nov. [central Vietnam]

2. Phryganistria fruhstorferi (Brunner von Wattenwyl, 1907) [Myanmar, S-China]

3. Phryganistria grandis Rehn, 1906 [Vietnam, Laos and Myanmar]

4. Phryganistria guanxiensis Chen \& He, 2008 [S-China (Guangxi)]

5. Phryganistria heusii heusii (Hennemann \& Conle, 1997) [northern Vietnam]

6. Phryganistria heusii yentuensis subsp. nov. [northeast Vietnam]

7. Phryganistria longzhouensis Chen \& He, 2008 [S-China (Guangxi)]

8. Phryganistria tamdaoensis sp. nov. [North \& central Vietnam]

9. Phryganistria virgea (Westwood, 1848) [NE-India, Bhutan, Sikkim, Darjeeling, Bangladesh \& Pulau Penang] syn. Phryganistria sarmentosa (Westwood, 1848)

\section{Keys to the species and subspecies of Phryganistria Stål, 1875}

\section{Note}

The two Chinese species described by Chen \& He (2008), P. guanxiensis and P. longzhouensis, are not included here because the specimens were not available for investigation.

\section{Females}

1. Cerci short, conical and cylindrical or oval in cross-section; not or very slightly projecting over the apex of the abdomen

- Cerci laterally compressed, enlarged and lanceolate, strongly projecting over apex of anal segment

P. tamdaoensis sp. nov. (Fig. 5A-F)

2. Subgenital plate short, indistinctly projecting over apex of anal segment, not lanceolate ......3

- Subgenital plate long and lanceolate, distinctly projecting over apex of anal segment ......5

3. Median segment at best $1 / 3$ the length of metanotum; dorsal carina of meso- and metabasi-

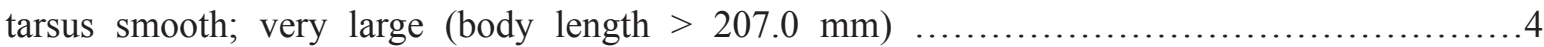

- Median segment $>1 / 3$ the length of metanotum; dorsal carina of meso- and metabasitarsus serrate; smaller species (body length $197.0 \mathrm{~mm}$ ) ...P. fruhstorferi (Brunner von Wattenwyl, 1907)

4. Terga II-VII smooth; posterolateral angles of anal segment tapered ...P. grandis Rehn, 1906

- Terga II-VII with a posteromedian granule; posterolateral angles of anal segment expanded and rounded

5. Terga III-VI laterally expanded and gently rounded; subgenital plate projecting over the anal segment by more than the combined length of terga VIII-X ...P. virgea (Westwood, 1848)

- Terga III-VI parallel-sided; subgenital plate projecting over the anal segment by less than the combined length of terga VIII-X P. bachmaensis (Ta \& Hoang, 2004) (Fig. 3A-F) 
BRESSEEL J. \& CONSTANT J., Pharnaciini from China and Vietnam (Phasmatodea: Phasmatidae)

6. Praeopercular organ formed by a pair of prominent, triangular, lobe-like spines

P. heusii heusii (Hennemann \& Conle, 1997)

- Praeopercular organ formed by a pair of rounded, lobe-like protuberances, rounded laterally .P. heusii yentuensis subsp. nov. (Fig. 8A-F)

\section{Males}

1. Meso- and metafemora robust and considerably broader than corresponding tibiae ........2

- Meso- and metafemora slender, not considerably broader than corresponding tibiae .........3

2. Prominent sub-apical spine on outer ventral carinae of meso- and metafemora, semi-tergites

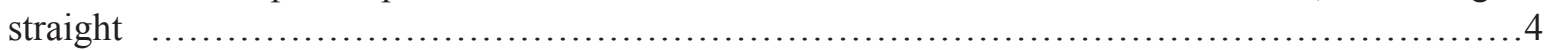

- No prominent sub-apical spine on outer ventral carinae of meso- and metafemora, semitergites strongly elongated and incurving ...P. bachmaensis (Ta \& Hoang, 2004) (Fig. 3I-N)

3. Median segment about $1 / 3$ the length of metanotum; body plain brown; no prominent sub-apical spine on outer ventral carinae; posteroventral carina of profemora dentate

P. virgea (Westwood, 1848)

- Median segment 2/5 the length of metanotum; thorax black laterally; no prominent sub-apical spine on outer ventral carinae; posteroventral carina of profemora unarmed (at best with two teeth)

P. fruhstorferi (Brunner von Wattenwyl, 1907)

4. Profemora pinkish, ventral carinae of meso- and metafemora blue with black spines, cerci flattened P. tamdaoensis sp. nov. (Fig. 5I-N)

- Profemora not pinkish, meso- and metafemora brown with black armature, cerci cylindrical in cross section .5 .

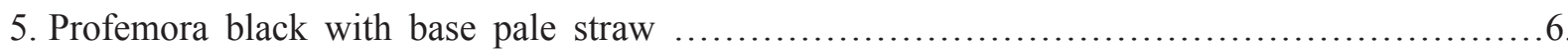

- Profemora plain brown ............................................. grandis Rehn, 1906

6. Greater portion of the mesonotum except anterior and posterior margin covered by a washed malachite green or creamish grey marking, meso- and metapleura coloured as body P. heusii heusii (Hennemann \& Conle, 1997)

- Body light brown, anterior portion of meso- and metapleura black

P. heusii yentuensis subsp. nov. (Fig. 8I-N)

Phryganistria bachmaensis (Ta \& Hoang, 2004) comb. nov.

Figs $3 \mathrm{~A}-\mathrm{N}, 4 \mathrm{~A}-\mathrm{M}, 10 \mathrm{~A}-\mathrm{B}$

Nearchus bachmaensis Ta \& Hoang, 2004: 15, figs 1-3

Note

In the original description (Ta \& Hoang 2004), the authors erroneously wrote "Nearchus bachmaensis Thinh et Tru sp. nov." due to the fact that, in Vietnamese, the family name is given first, i.e., in Ta Huy Thinh and Hoang Vu Tru, Ta and Hoang are the family names and Thinh and Tru the first names, respectively.

\section{Type material examined}

Holotype ổ, Bach Ma National Park, Tri Sao, Thuathen-Hue Province, Vietnam, 26 Jul. 2001 (IEBR).

Paratype + , same data as holotype (IEBR). 


\section{Additional material examined}

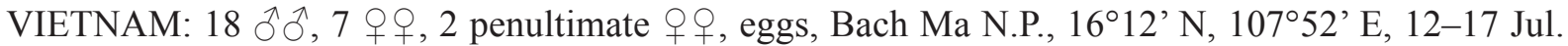
2011, leg J. Constant \& J. Bresseel, I.G. 31.933 (RBINS); 1 ð, Da Krong Nat. R., Quang Tri Prov. $16^{\circ} 37^{\prime}$ N, $106^{\circ} 47^{\prime}$ E, 5-10 Jul. 2011, leg. J. Constant \& J. Bresseel, I.G. 31.933 (RBINS).

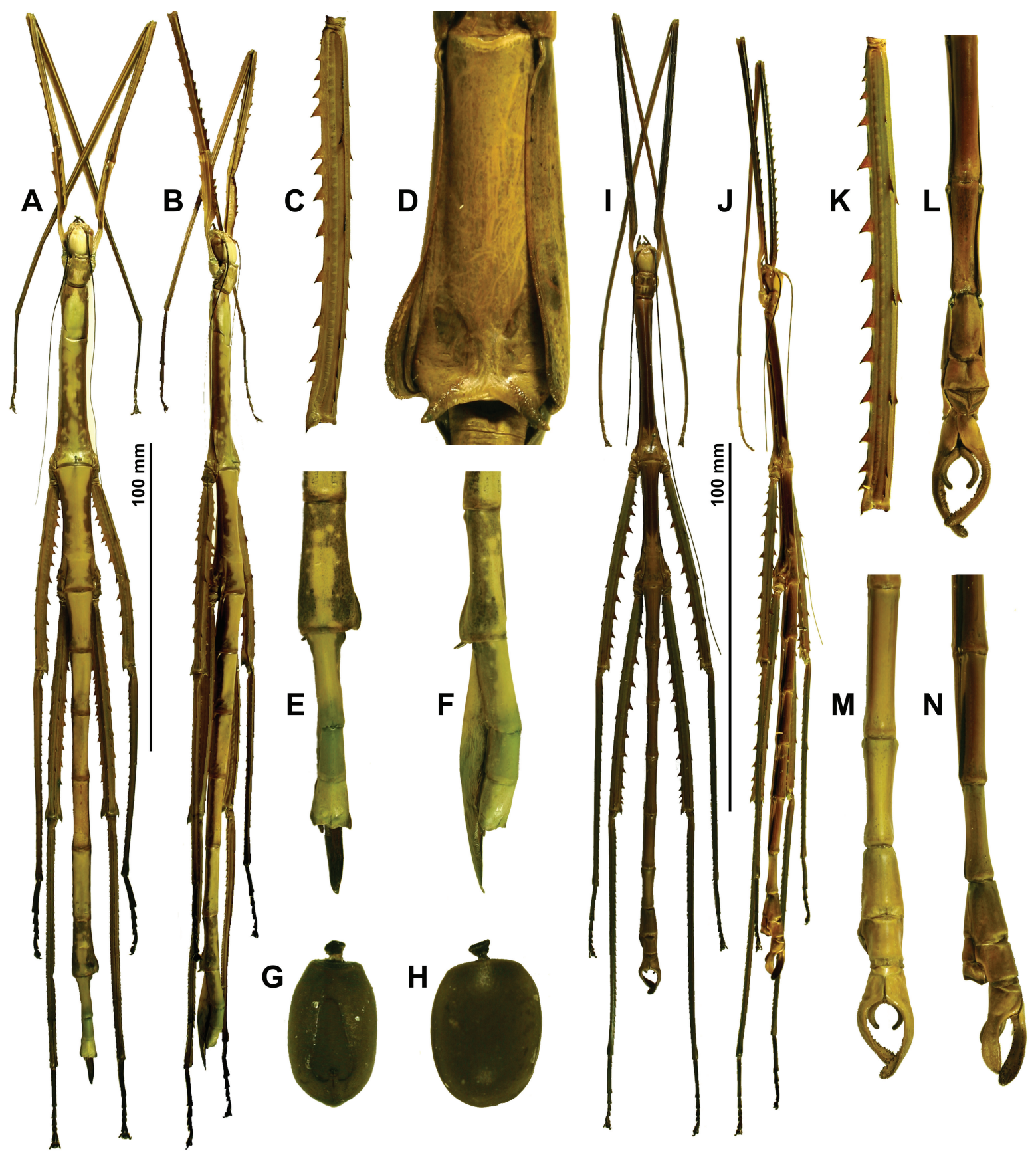

Fig. 3. Phryganistria bachmaensis (Ta \& Hoang, 2004) comb. nov. - A-F. $\odot$. A. Habitus, dorsal view. B. Habitus, lateral view. C. Mesofemur, lateral view. D. Sternum VII and praeopercular organ. E. Apex of abdomen, dorsal view. F. Apex of abdomen, lateral view. - G-H. Egg. G. Dorsal view. H. Lateral view. - I-N. $\widehat{\jmath}$. I. Habitus, dorsal view. J. Habitus, lateral view. K. Mesofemur, lateral view. L. Apex of abdomen, ventral view. M. Apex of abdomen, dorsal view. N. Apex of abdomen, lateral view. C-H, $\mathrm{K}-\mathrm{N}=$ not to scale. 
BRESSEEL J. \& CONSTANT J., Pharnaciini from China and Vietnam (Phasmatodea: Phasmatidae)

\section{Differentiation}

This distinctive species is easily recognised. Males are the only representatives of the genus with strongly elongated and incurving semi-tergites. Females share the elongated subgenital plate with Phryganistria virgea (Westwood, 1848) but lack the lobed abdominal terga III-VI.

\section{Description}

The colouration is described from photographs of live specimens. Measurements: see Table 1.
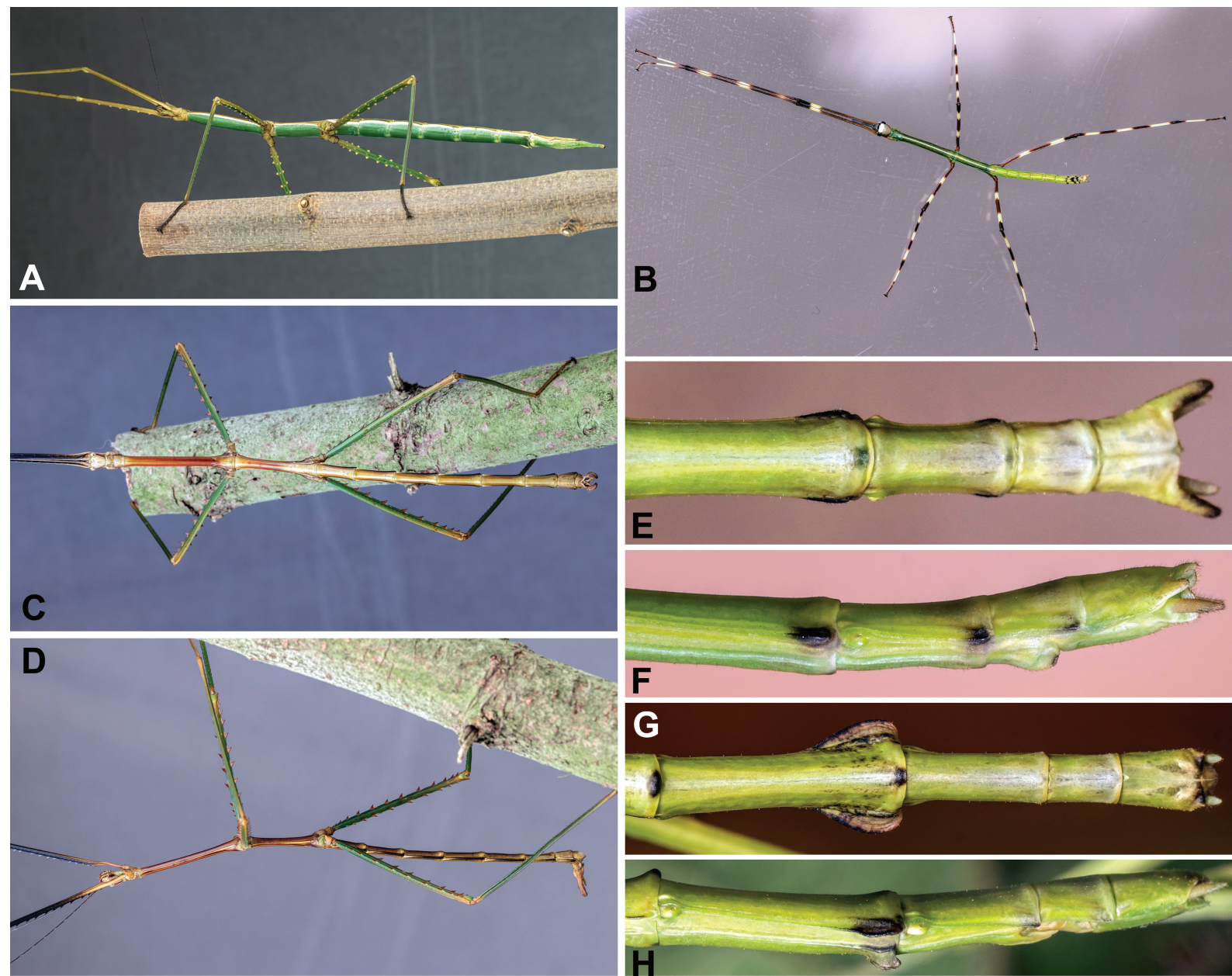

E
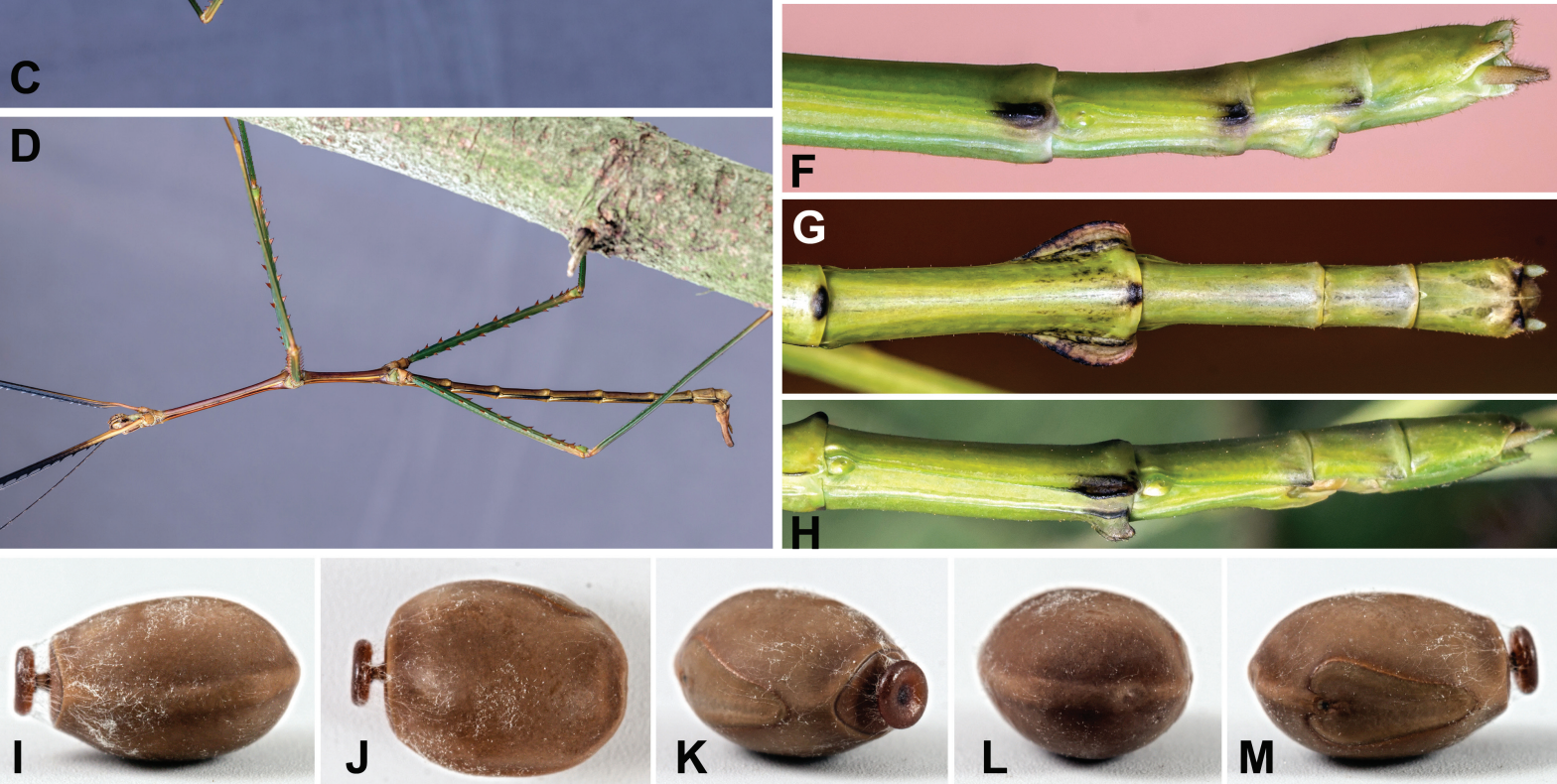

Fig. 4. Phryganistria bachmaensis (Ta \& Hoang, 2004) comb. nov., captive reared (photographs by Dr Bruno Kneubühler). A. + , ventral view. B. Freshly hatched nymph. C. $\hat{\jmath}$, dorsal view. D. $\widehat{\partial}$, ventrolateral view. - E-F. $3^{\text {rd }}$ instar male nymph, apex of abdomen. E. Dorsal view. F. Lateral view. - G-H. $4^{\text {th }}$ instar 9 nymph, apex of abdomen. G. Dorsal view. H. Lateral view. - I-M. Egg. I. Ventral view. J. Lateral view. K. Detail of operculum and capitulum. L. Polar area. M. Detail of micropylar plate. 
Table 1. Measurements (mm) of Phryganistria bachmaensis (Ta \& Hoang, 2004)

\begin{tabular}{|lcc|}
\hline & 우 & \multicolumn{1}{c}{$\hat{\jmath}$} \\
\hline Body & $261.0-291.0$ & $192.0-221.0$ \\
Head & $11.9-13.2$ & $9.3-9.8$ \\
Pronotum & $9.2-10.5$ & $5.7-7.2$ \\
Mesonotum & $50.4-56.3$ & $39.9-45.8$ \\
Metanotum & $26.5-29.5$ & $22.9-25.3$ \\
Median segment & $8.5-9.9$ & $7.8-9.6$ \\
Profemora & $71.7-82.7$ & $64.2-74.9$ \\
Mesofemora & $52.9-62.7$ & $49.9-54.6$ \\
Metafemora & $59.9-69.2$ & $56.7-62.4$ \\
Protibiae & $98.3-112.7$ & $92.0-100.0$ \\
Mesotibiae & $59.8-71.5$ & $59.0-62.0$ \\
Metatibiae & $73.9-87.9$ & $71.0-77.4$ \\
\hline
\end{tabular}

Male (Figs 3I-N, 4C-F, 10B)

BoDy. Large and robust, widest part of body (posterior part of mesothorax) up to $9.5 \mathrm{~mm}$. Body surface smooth and glabrous.

Colouration. Distinctive and very characteristic. Head pale, cream-brown with dark brown postocular line. Genae also with dark brown longitudinal stripe. Central portions of pro,- meso- and metanotum reddish brown with anterior and posterior portions paler. Abdominal terga orange-brown with black longitudinal markings laterally. Profemora black with basal portion cream-brown. Apices of profemora and protibiae orange-brown. Meso- and metafemora and -tibiae green with reddish brown armature. Tarsi coloured darker than corresponding tibiae.

HEAD. Smooth, about $1.5 x$ longer than wide. Eyes relatively large and strongly projecting. Transverse oval impression between antennae and very shallow irregularly shaped depression between eyes. Antennae surpassing abdominal segment II. Scapus and pedicellus coloured as head, antennomeres dark brown to black.

Thorax. Pronotum shorter and narrower than head. Anterior margin raised and incurved, followed by transverse depression. Pronotum with longitudinal depression not reaching posterior margin and another central transverse depression. Narrowest part anteriorly, widest part posteriorly. Mesonotum elongated and smooth, posterior portion widened. Metanotum as mesonotum, about 3.2x length of median segment.

AbDomen. Median segment trapezoidal and smooth. Terga II-VI only slightly differing in length and cylindrical in cross section. Anterior margins indistinctly incurving. Tergum VII about $4 / 5$ of segment VI and widening posteriorly. Tergum VIII about half of abdominal segment VII. Tergum IX tectiform and about $2 / 3$ of tergum VIII. Anal segment about as long as VIII and IX combined. Basal portion laterally compressed with distinct carina dorsally, splitting into two semi-tergites. Semi-tergites laterally flattened, strongly elongated and incurved with apices rounded. Interior surface with small black teeth. Teeth denser near edges and apex of semi-tergites. Cerci elongated, cylindrical in cross section and 
conspicuously incurved, apices rounded. Poculum knob-like with distinct longitudinal carina, projecting just beyond apex of tergum IX.

Legs. Profemora slightly shorter than metatibiae, incurving basally and anterodorsal carinae with 14-20 saw-like teeth. Other carinae unarmed. Protibiae carinate, posteroventral carinae with small saw-like serrations, roughly $1.3 \mathrm{x}$ the length of profemora. Mesofemora almost as long as mesonotum and pronotum combined. Outer ventral carinae armed with 10-14 saw-like teeth, central teeth largest. Medioventral carinae with few minute spines. Dorsal carinae armed with 3-5 smaller saw-like teeth. Mesotibiae about as long as metafemora. Dorsal carinae with few minute serrations. Ventral carinae strongly serrated. Metafemora and metatibiae as mesofemora and mesotibiae. All tarsomeres with distinct dorsal carina. Probasitarsus about as long as head and pronotum combined. Meso- and metabasitarsus about as long as following tarsomeres combined. Claws prominent.

Female (Figs 3A-F, 4A, G-H, 10A)

Colouration. Variable. Overall dorsal colouration light brown with a green shade, one specimen mottled green and light brown. Ventral colouration green. Lateral edges of pro-, meso- and metasternum and abdominal sterna with white longitudinal line. Mesopleurae black. Bases of praeopecular organ with short longitudinal black line. Profemora and -tibiae light brown. Meso- and metafemora and corresponding tibiae coloured greenish brown with armature reddish brown and tipped black. Tarsi and claws blackish.

HEAD. Vertex with faint median line. Oval, about 1.6x longer than wide, vertex rounded. Between bases of antennae, transverse oval impression and two faint circular impressions between eyes. Eyes large, circular and strongly convex. Antennae with scapus dorsoventrally flattened and more or less rectangular in dorsal aspect. Last antennomere reaching about halfway along metathorax.

THORAX. Pronotum narrower and shorter than head, anterior margin narrower than posterior one, $1.4 \mathrm{x}$ longer than wide. Anterior margin raised and followed by transverse depression. Second transverse depression at about half length of pronotum. Faint longitudinal depression centrally not reaching anterior or posterior margin. Mesothorax about 5.4x length of pronotum. Mesonotum damaged during drying process in all specimens, wrinkled anteriorly. Surface smooth, more or less parallel-sided. Metanotum about half the length of mesonotum, parallel-sided. Pleurae and sterna simple.

Abdomen. Median segment transverse, about $1 / 3$ the length of metanotum. Segments II-VI slightly increasing in length. Tergum VII about $4 / 5$ the length of VI with distinct, rounded lobe posterolaterally. Sternum VII with distinct bifurcate praeopercular organ at posterior margin. Praeopercular organ formed by a pair of definite, diverging spines, slightly projecting over margin of sternum VIII. Tergum VIII distinctly narrower than previous, about $3 / 4$ as long as VII; IX less than half the length of VIII. Anal segment hardly longer than IX, slightly broader towards apex, with faint median carina and strongly notched postero-medially. Postero-lateral angles acute. Supra-anal plate small, surpassing posterolateral angles of tergum IX, tectiform with fine median carina, apex rounded. Cerci short, more or less cylindrical, rounded at apex and slightly surpassing supra-anal plate. Gonapophyses elongated, up-curving and reaching apex of subgenital plate. Subgenital plate keeled and strongly projecting over apex of abdomen, apex acute.

Legs. All long and rather robust. Profemora slightly longer than metatibiae, incurving basally and with 14-20 saw-like teeth on anterodorsal carinae. Outer ventral carina with 7-9 saw-like teeth. Protibiae carinate, posteroventral carinae with small, saw-like serrations, roughly $1.4 \mathrm{x}$ longer than profemora. Metafemora reaching about halfway tergum III. Outer ventral carinae armed with 8-13 strong, saw-like teeth. Medioventral carinae with 6-8 small, acute spines. Inner dorsal carinae armed with 4-8 saw-like teeth, outer dorsal carinae with 3-5 minute teeth. Mesotibiae reaching about halfway tergum VI, all ventral carinae strongly serrated. Dorsal carinae with few minute serrations. Metafemora and metatibiae 
as mesofemora and mesotibiae. All tarsomeres with distinct dorsal carina, triangular in cross section. Claws prominent.

Egg (Figs 3G-H, 4I-M)

Capsule oval in lateral aspect, rounded at polar area, slightly compressed laterally and oval in crosssection. Capsule with relatively wide carina on ventral surface and polar area, reaching micropylar plate, and indistinct small impression on polar area. Capsule surface smooth, brown and dull. Micropylar plate coloured as capsule with darker margin, large, covering about 2/3 of dorsal capsule surface. Micropylar plate elongated, rounded towards anterior end. Broader posteriorly, posteromedially with distinct gap. Micropylar cup small, blackish, placed in posteromedial gap of plate. Median line short and projecting over posterior margin of plate. Operculum oval, coloured as capsule with darker outer margin. Capitulum large, reddish brown, concave with darker centre. Stalk obvious.

Measurements (mm): length including capitulum 5.0, length 4.3, width 3.0, height 3.5.

Nymph (Fig. 4B)

Newly hatched 20 to $25 \mathrm{~mm}$ long. Head pale with white marking between eyes. Eyes black and antennae short, black and consisting of eight segments. Apical segment strongly elongated, longer than five preceding segments together. Median segment, pro-, meso- and metanotum bluish-green. Meso- and metanotum with black line laterally. Abdominal terga II-VI green. Terga VII-IX with more or less triangular black marking posteromedially and posterolateral edges tipped black. Abdominal tergum $\mathrm{X}$ whitish, cerci small, whitish and setose.

Procoxae and first portion of profemora orangish. Apical portion with white transverse marking, followed by brown transverse band. Protibiae brown with two transverse white bands. Meso- and metacoxae brown. Meso- and metafemora brown with two transverse white bands. Meso- and metatibiae brown with three transverse white bands. Basitarsi with large transverse white band, other tarsi and claws brown. Claws small.

\section{Remarks}

At the time of description this species was placed in the genus Nearchus Redtenbacher, 1908, most probably due to the elongated subgenital plate of the female. Hennemann \& Conle (2008: 129) synonymised Nearchus Redtenbacher, 1908 with Phobaeticus Brunner von Wattenwyl, 1907; hence, the genus name is no longer valid. The key provided by Hennemann \& Conle (2008: 82) clearly places N. bachmaensis in genus Phryganistria Stål, 1875. Hence, it is here transferred to that genus.

Eggs of this species were collected by the authors in 2011 from Bach Ma National Park and the species was cultured by Dr. Bruno Kneubühler. Bramble (Rubus spp., Rosaceae) was accepted as alternative foodplant by all instars. Beech (Fagus sylvatica, Fagaceae), hazel (Corylus avellana, Betulaceae), salal (Gaultheria shallon, Ericaceae) and oak (Quercus spp., Fagaceae) were readily eaten by older nymphs and adults (not tested on newly hatched nymphs). Matings were frequently observed and the males remained coupled with the females for 1-2 days. In the wild females are also mostly accompanied by a male, the male clinging to the female. No difficulties were observed when rearing this species.

\section{Distribution}

The type locality of this species is Bach Ma National Park. Its distribution is here extended to Da Krong Nature Reserve (Fig. 12A). 
BRESSEEL J. \& CONSTANT J., Pharnaciini from China and Vietnam (Phasmatodea: Phasmatidae)

\section{Phryganistria tamdaoensis sp. nov. urn:1sid:zoobank.org:act:C4297AF4-F327-49A5-B8C1-716FCD500C8C}

Figs $5 \mathrm{~A}-\mathrm{N}, 6 \mathrm{~A}-\mathrm{M}, 7 \mathrm{~A}-\mathrm{J}, 10 \mathrm{E}-\mathrm{H}$

\section{Diagnosis}

This species can be this distinguished from other representatives of the genus by the flattened cerci. In females these are also conspicuously enlarged.

\section{Etymology}

This species is named after the beautiful Tam Dao National Park. Specimens were firstly collected from this locality where the species is common.

\section{Type material}

Holotype

VIETNAM: đ’, Tam Dao N.P. 2131’ N, 105³3’ E, 25-30 Jul. 2011, leg. J Constant \& J. Bresseel, I.G. 31.933 (RBINS).

Paratypes $(22 \hat{\delta}, 22 \propto+\phi, 50$ eggs)

VIETNAM: 1 + Tam Dao, 25-28 Aug. 2010, I.G. 31.668, leg J. Constant \& P. Limbourg (RBINS); 9

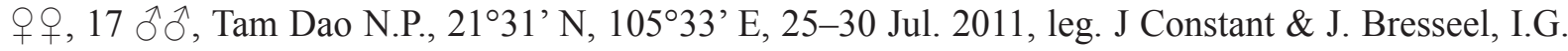

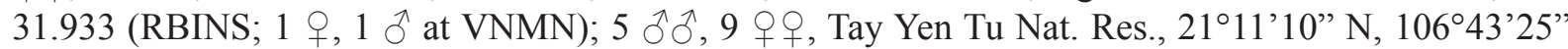
E, 7-11 Jul. 2013, leg. J. Constant \& J. Bresseel, I.G. 32.454 (RBINS). 3 우, 50 eggs, ex breeding J.

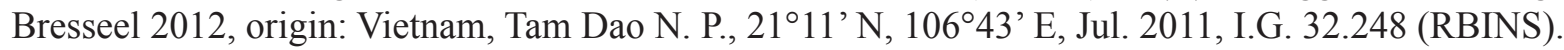

Additional material examined $(2 \precsim ふ, 1$ $)$

VIETNAM: 1 , , Da Krong Nat. R., Quang Tri Prov. $16^{\circ} 37^{\prime}$ N, $106^{\circ} 47^{\prime}$ E, 5-10 Jul. 2011, leg. J. Constant \& J. Bresseel, I.G. 31.933 (RBINS); 2 đô, 40 eggs, ex breeding B. Kneubühler, origin: Vietnam, Da Krong Nat. R., Quang Tri Prov. 16³7’ N, 106² 47’ E, 5-10 Jul. 2011, leg. J. Constant \& J. Bresseel, I.G. 32.387 (RBINS).

\section{Differentiation}

Most closely related to Phryganistria heusii heusii (Hennemann \& Conle, 1997) and Phryganistria grandis Rehn, 1906. Males share the broadened meso- and metafemora. The enlarged subapical spine on the outer ventral carinae of meso- and metafemora is present, but not as pronounced as in the other two species. Males can also easily be distinguished by their body colouration: mesonotum bluish green and anterior legs not black. Females can be distinguished from all other species in the genus by the enlarged, flattened and lanceolate cerci.

\section{Description}

The colouration is described from photographs of live specimens. Measurements, see Table 2.

Male (Figs 5I-N, 6D, 7C, I-J)

Body. Medium sized and robust for the genus, widest part of the body up to $9.3 \mathrm{~mm}$. Body surface smooth and shiny, colouration very distinct.

Colouration. Head and pronotum golden brown. Genae with brown line reaching from occiput to eyes. Anterior and posterior portion of mesonotum and mesosternum golden brown, central areas clear blue. Mesonotum with lateral black line. Posterior part of mesopleura black, anterior part golden brown. Metanotum and metasternum coloured as previous. Metapleura black. Median segment and abdominal 
terga coloured golden brown. First sterna with some blue markings, others golden brown. Femora with carinae blue, area between carinae pink, spines black. Tibiae and tarsomeres pinkish-brown.

HEAD. Smooth, 1.5x longer than wide. Eyes relatively large and strongly projecting. Two shallow crescent-shaped impressions between eyes and a transverse impression between antennae. Antennae reaching posterior margin of median segment. Scapus and pedicellus coloured as head, remaining antennomeres black.

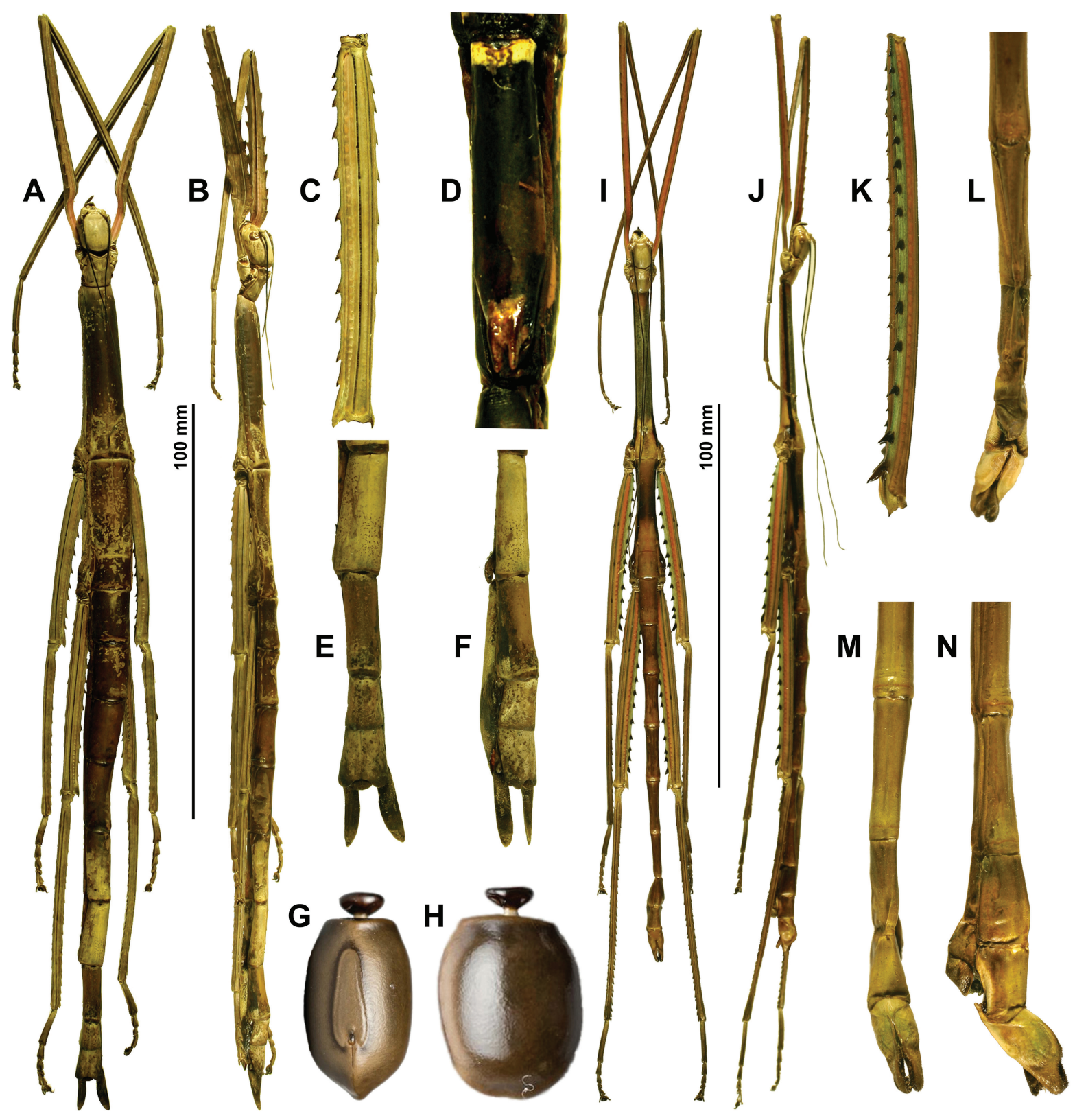

Fig. 5. Phryganistria tamdaoensis sp. nov. - A-F. ․ A. Habitus, dorsal view. B. Habitus, lateral view. C. Mesofemur, lateral view. D. Sternum VII and praeopercular organ. E Apex of abdomen, dorsal view. F. Apex of abdomen, lateral view. - G-H. Egg. G. Dorsal view. H. Lateral view. - I-N. đ. I. Habitus, dorsal view. J. Habitus, lateral view. K. Mesofemur, lateral view. L. Apex of abdomen, ventral view. M. Apex of abdomen, dorsal view. N. Apex of abdomen, lateral view. $\mathrm{C}-\mathrm{H}, \mathrm{K}-\mathrm{N}=$ not to scale. 
BRESSEEL J. \& CONSTANT J., Pharnaciini from China and Vietnam (Phasmatodea: Phasmatidae)

THORAX. Pronotum shorter and narrower than head, with slight longitudinal depression and deeper, central transverse depression. Narrowest part in centre, widest part posteriorly. Anterior margin incurving, posterior margin convex. Mesonotum elongated and smooth. Mesothorax with posterior portion as widest part of body. Metanotum as mesonotum, about 3.5x length of median segment.

AвDomen. Median segment trapezoidal and smooth. Terga II-VI slightly increasing in length and cylindrical in cross section. Segment VII about as long as segment II. Tergum VIII about $2 / 3$ of segment VII and wider posteriorly. Tergum IX about half of abdominal segment VII but more compressed laterally, lateral margins with pale marking. Anal segment laterally compressed with distinct carina dorsally, splitting halfway into two semi-tergites. Semi-tergites roughly triangular in lateral aspect, broad anteriorly and tapered apically. Apices narrow and rounded. Interior surface apically swollen with small black teeth. Cerci elongated and flattened, broadening towards apex; these rounded and not
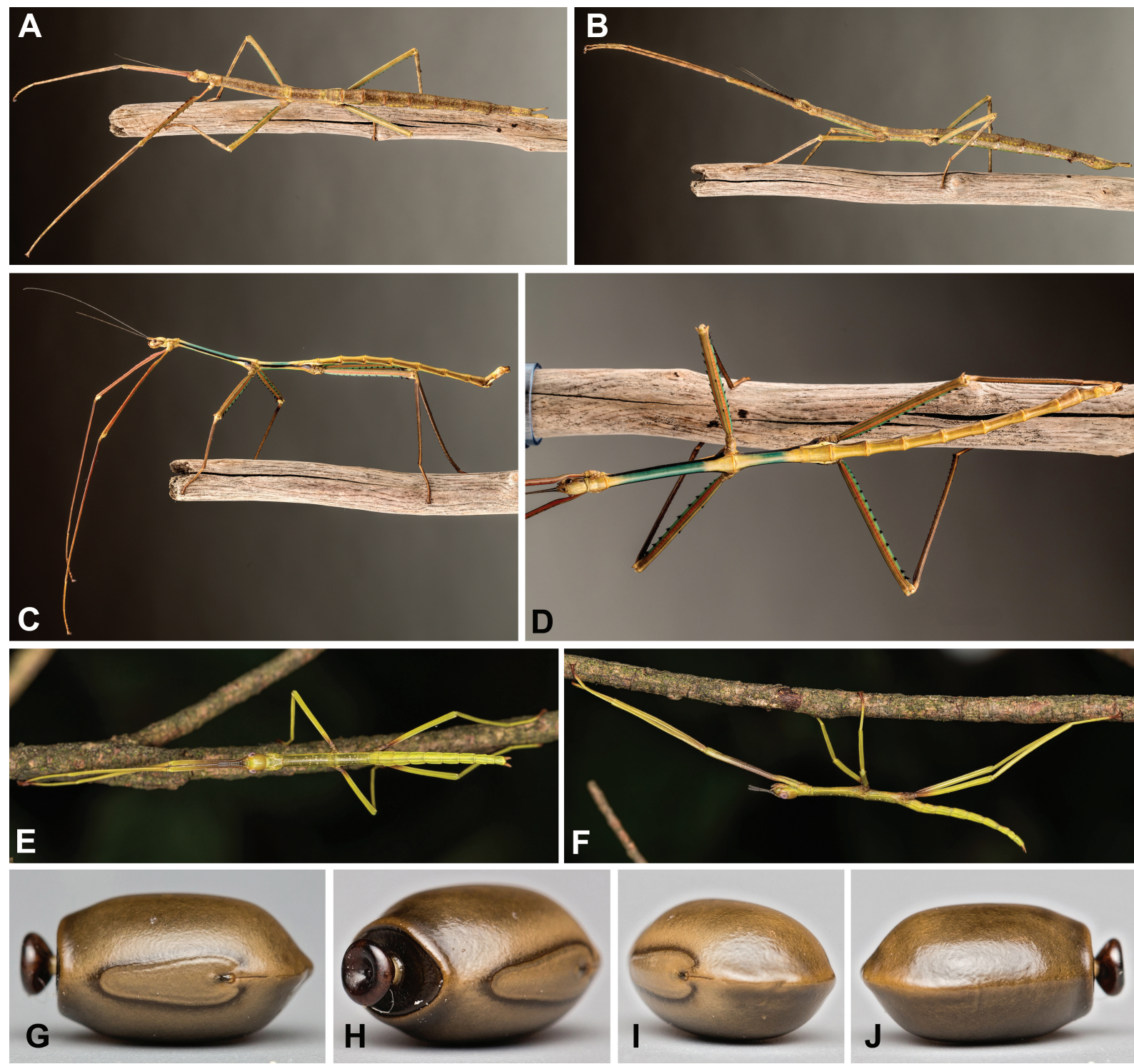

Fig. 6. Phryganistria tamdaoensis sp. nov., captive reared, from Tam Dao N.P. (photographs by Dr Bruno

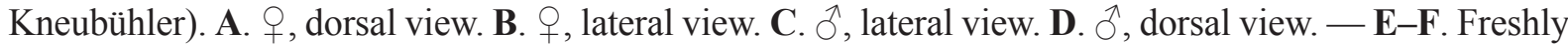
hatched nymph. E. Dorsal view. F. Lateral view. - G-J. Egg. G. Dorsal view. H. Detail of operculum and capitulum. I. Polar area. J. Ventral view. 
Table 2. Measurements (mm) of Phryganistria tamdaoensis sp. nov.

\begin{tabular}{|c|c|c|c|}
\hline & Holotype $\widehat{\sigma}$ & Paratypes $q q+$ & Paratypes $\widehat{\partial} \widehat{\lambda}$ \\
\hline Body & 190.6 & $203.9-228.7^{*}$ & $165.5-202.8$ \\
\hline Head & 9.7 & $12.3-13.9$ & $9.0-9.8$ \\
\hline Pronotum & 6.5 & $7.9-9.0$ & $5.9-6.8$ \\
\hline Mesonotum & 42.5 & $42.9-46.7$ & $36.2-45.9$ \\
\hline Metanotum & 24.4 & $21.7-24.9$ & $20.1-26.6$ \\
\hline Median segment & 6.9 & $8.2-9.3$ & $6.2-7.7$ \\
\hline Profemora & 56.8 & $58.3-59.3$ & $51.9-60.8$ \\
\hline Mesofemora & 42.9 & $42.8-44.4$ & $37.7-43.9$ \\
\hline Metafemora & 47.7 & $45.9-49.9$ & $45.6-48.4$ \\
\hline Protibiae & 77.8 & $69.8-77.1$ & $67.6-79.6$ \\
\hline Mesotibiae & 49.1 & $42.9-45.0$ & $41.6-50.6$ \\
\hline Metatibiae & 60.3 & $47.0-56.7$ & $53.0-64.6$ \\
\hline Cerci & - & $>10.0$ & - \\
\hline
\end{tabular}

* excluding cerci

reaching posterior margin of anal segment. Poculum with distinct longitudinal carina, reaching about $2 / 3$ along tergum IX.

LEGS. Profemora slightly longer than combined length of head, pro- and mesonotum, incurving basally and with anterodorsal carinae showing 8-12 black saw-like teeth. Some specimens have one or two black teeth on posteroventral carinae. Protibiae carinate but unarmed, roughly $1.3 \mathrm{x}$ the length of profemora. Mesofemora distinctly swollen, about as wide as centre of mesonotum and as long as mesonotum. Outer ventral carinae armed with 10-16 black saw-like teeth, last two teeth prominently enlarged. Medioventral carinae with 6-11 smaller spines. Dorsal carinae unarmed or with few minute teeth. Mesotibiae about as long as metafemora. Dorsal carinae unarmed or with few minute teeth. Outer ventral carinae strongly armed with saw like teeth. Medioventral carinae with minute incurving spines starting at about $1 / 3$ from base, spines more numerous towards apex. Metafemora and metatibiae as mesofemora and mesotibiae. All tarsomeres with distinct dorsal carina. Probasitarsus about as long as head and pronotum combined. Meso- and metabasitarsus about as long as following tarsomeres combined. Claws prominent.

Female (Figs 5A-F, 6A-B, 7A-B)

BoDy. Medium sized and quite broad for the genus.

Colouration. Overall colour of female light brown to dull green with brown mottling. Profemora pinkish in curved basal portion. Carinae of other femora with bluish hue and with some pinkish markings between carinae.

HEAD. Oval, about 1.6x longer than wide, vertex rounded. Transverse impression between bases of antennae, and two very faint impressions between eyes. Eyes quite large, circular and convex. Antennae with scapus dorsoventrally flattened and rectangular. Pedicellus short, $1 / 3$ the length of scapus and 
BRESSEEL J. \& CONSTANT J., Pharnaciini from China and Vietnam (Phasmatodea: Phasmatidae)

cylindrical. Antennomere III about as long as pedicellus, III-XVIII gradually increasing in length, the following decreasing in length, the terminal antennomeres very short.

Thorax. Pronotum narrower and shorter than head, anterior margin slightly narrower than posterior margin, 1.3x longer than wide. Anterior margin raised and followed by transverse depression. Second transverse depression at about half length of pronotum, not reaching lateral margins. Faint longitudinal depression not reaching anterior or posterior margin. Mesothorax 5-5.5x length of pronotum. Mesonotum
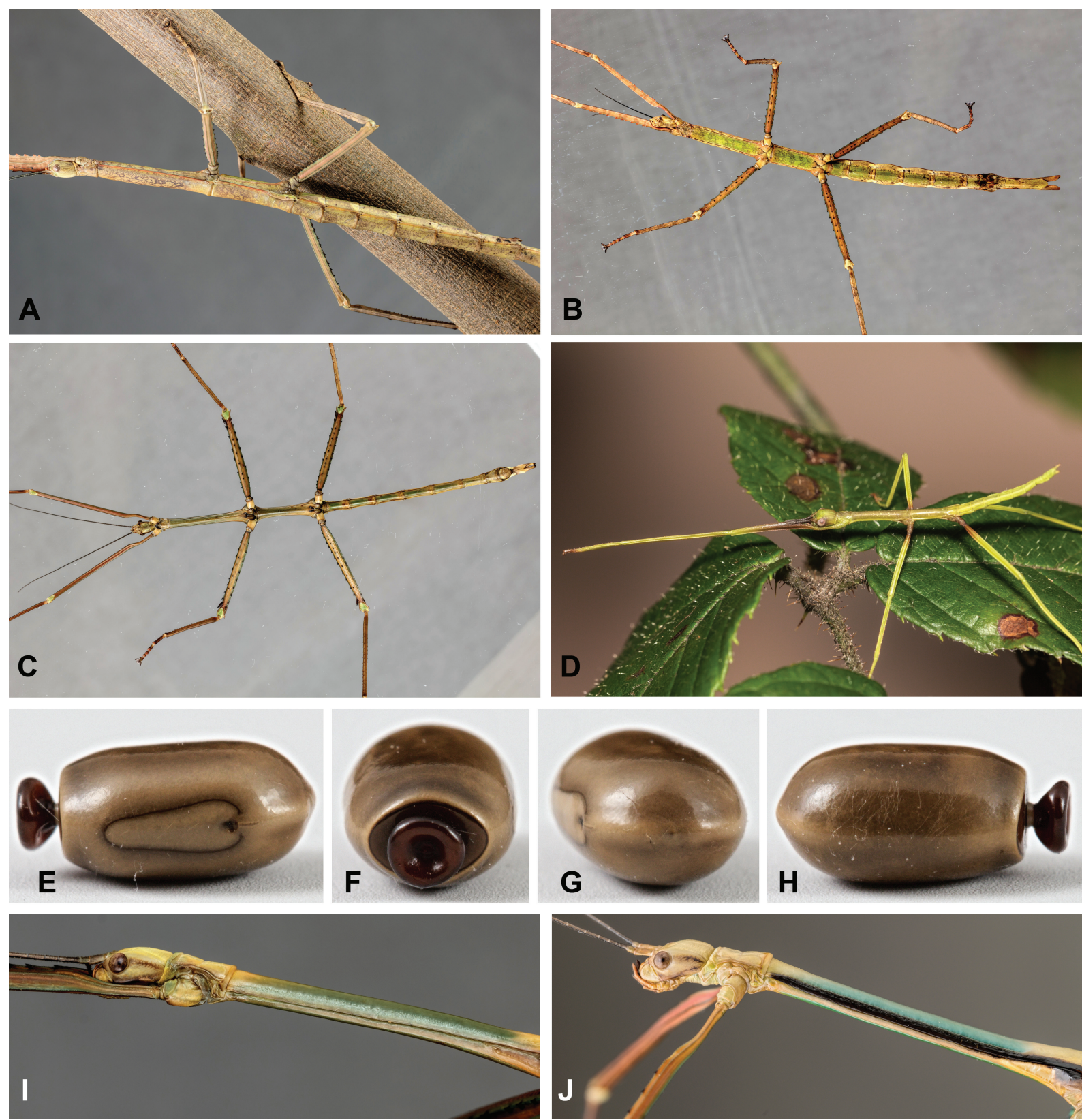

Fig. 7. Phryganistria tamdaoensis sp. nov. (photographs by Dr Bruno Kneubühler). - A-I. Captive

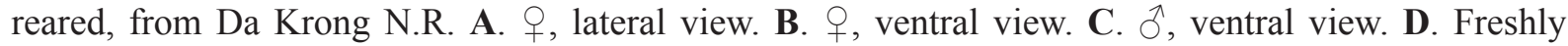
hatched nymph. - E-H. Egg. E. Dorsal view. F. Detail of operculum and capitulum. G. Polar area. H.

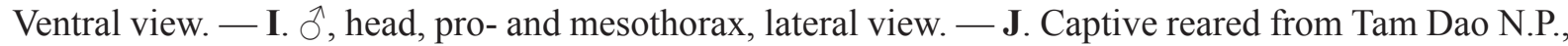
$\hat{\gamma}$, head, pro- and mesothorax, lateral view. 
smooth, parallel-sided, slightly broadening posteriorly. Metanotum slightly more than half length of mesonotum, parallel-sided. Pleurae and sterna simple.

ABdomen. Median segment transverse, about $1 / 3$ as long as metanotum, rectangular. Segments II-VI slightly increasing in length and very slightly, gradually narrowing (II-IV broadest), II 1.3x, VI almost $2.5-3 \mathrm{x}$ longer than wide. Tergum VII about $4 / 5$ as long as VI, with small, rounded lobe posterolaterally. Sternum VII with distinct praeopercular organ at posterior margin. Praeopercular organ formed by a pair of definite spines, slightly projecting, surpassing margin of sternum VIII. Tergum VIII distinctly narrower than previous one, about $4 / 5$ as long as VII. IX half as long as VIII. Anal segment hardly longer than IX, somewhat broader apically, with faint median carina and almost semi-circular median incision at posterior margin. Posterolateral angles narrowed and rounded apically. Supra-anal plate small, semicircular and with fine median carina, reaching apex of anal segment. Cerci flattened, strongly lanceolate and rounded at apex, almost $1.5 \mathrm{x}$ as long as anal segment. Gonapophyses elongated, up-curving and slightly surpassing apex of subgenital plate. Subgenital plate keeled, boat-shaped, almost reaching apex of anal segment

Legs. All moderately long and fairly robust. Profemora longer, mesofemora as long as mesonotum, metafemora almost reaching apex of abdominal segment V. Anterodorsal and posteroventral carina of profemora armed with 8-13 prominent, triangular serrations. Other leg armature as in male but last two teeth on outer ventral carinae of meso- and metafemora not prominently enlarged.

Egg (Figs 5G-H, 6G-J, 7E-H)

Large, capsule oval in lateral aspect, slightly impressed at polar-area, slightly compressed laterally and oval in cross-section. Capsule with distinct keel beginning at medium line of micropylar plate, crossing polar area and ventral surface, and ending at operculum. Capsule surface smooth and dull. General colouration of capsule and micropylar plate light brown, operculum blackish. Micropylar plate elongated, tapering towards anterior end and with distinct gap posteromedially. Outer margin dark. Micropylar cup small and dark brown, placed in posteromedian gap of plate. Median line present and distinctly projecting over posterior margin of plate. Operculum oval and slightly concave, outer margin raised. Capitulum brownish, strongly concave and relatively large. Stalk obvious, whitish.

Measurements (mm): length including capitulum 6, length 5.2, width 2.7, height 3.7.

Nymph (Figs 6E-F, 7D)

Newly hatched 20 to $25 \mathrm{~mm}$ long, general body colouration green. Meso- and metanotum slightly darker with some minute white spots. Central portion of profemora and bases of meso- and metafemora coloured reddish brown. Antennae brown, very short, not reaching halfway along profemora. Apical tarsi and claws brown.

\section{Remarks}

The typical egg, the length of the median segment (about $1 / 3$ of the metanotum in females and $1 / 4$ in males) and the presence of a praeopercular organ place this species in Phryganistria Stål, 1875.

This species violates one of the key features of Phryganistria Stål, 1875 proposed by Hennemann \& Conle (2008). According to these authors, Phryganistria have a median segment that is longer than wide and at least $1 / 5$ the length of the metanotum. However, females of this species have a transverse median segment. This nonconformity does not cause problems in any other genus of Pharnaciini except Baculonistria Hennemann \& Conle, 2008 which has a transverse median segment, but has a median segment of $1 / 8$ the length of the metanotum. 
The flattened and strongly lanceolate cerci in females are characters commonly found in Phasmatinae sensu Henneman \& Conle 2008. The cerci of Clitumninae are usually small and shorter than the anal segment, cylindrical to sub-cylindrical in cross-section, but can also be laterally compressed or slightly lanceolate (Hennemann \& Conle 2008). The laterally flattened and enlarged foliacous or lanceolate cerci are one of the five apomorphic characters to support the monophyly of Bradler's (2001) Lanceocercata. However, the presence of a praeopercular organ on sternum VII in females and the profemora with the medioventral carina strongly displaced towards the anteroventral carina place this species in Clitumninae.

The material from Da Krong Nature Reserve is excluded from the type material as there are several characters that differ from specimens from Tam Dao N.P. and Tay Yen Tu Nature Reserve. Males lack the lateral black markings on meso- and metathorax (Fig. 7I-J) and have the semi-tergites tapering more gradually. Females have slightly more elongated lobes of the praeopercular organ and comparatively more rounded cerci. The eggs have smaller dimensions and are more strongly laterally compressed.

Also, since this locality is relatively distant from the type locality, more material from in between both localities is needed to support a possible subspecies rank.

Eggs of this species were collected by the authors in 2011 from Tam Dao National Park and Da Krong Nature Reserve. The culture stock from Da Krong Nature Reserve was cultured by Dr. Bruno Kneubühler and the culture stock from Tam Dao N. P. was reared by the first author. Bramble (Rubus spp., Rosaceae) and oak (Quercus spp., Fagaceae) were very well accepted as alternative foodplants. The species is still cultured by several enthusiasts around Europe from eggs collected by the authors from Tam Dao National Park (Fig. 6) and Da Krong Nature Reserve (Fig. 7).

\section{Distribution}

This species is recorded from Tay Yen Tu Nature Reserve, Tam Dao National Park and Da Krong Nature Reserve. However, it is likely that this species is more widespread considering the distance between these localities (Fig. 12 B).

Phryganistria grandis Rehn, 1906

Phryganistria grandis Rehn, 1906: 279, figs 1-2 (ð). Holotype, §̊: Tonkin, Indo-China (ANSP).

\section{Material examined}

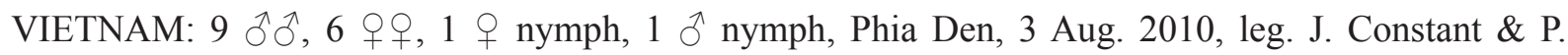
Limbourg, I.G. 31.668 (RBINS).

\section{Comments}

Hennemann \& Conle (2008: 205) differentiate the male of $P$. grandis from the closely related species $P$. heusii heusii by the brown colour of their profemora, the absence of spines on the postero-ventral carinae of the profemora and the elongated and slender cerci \pm reaching the apex of the anal segment. Colouration of the profemora is constant in all the material examined in this study. The absence of spines on the postero-ventral carinae of the profemora has been oberved in the majority of the specimens; however, several specimens from Phia Den have a few small saw-like spines on the outer ventral carinae. The differentiation by the cerci could not be confirmed and therefore both characters are here excluded from the key.

In the material examined by Hennemann \& Conle (2008: 205) there are some questions regarding the identity of certain specimens: 
The records by Hennemann \& Conle (2008: 205) of Phryganistria grandis Rehn, 1906 from Vietnam, Cochin China based on material from Mount Bavi and Tuyen Quang is erroneous: both localities are in North Vietnam: the coordinates of Mount Bavi are $21^{\circ} 01^{\prime}-21^{\circ} 07^{\prime} \mathrm{N}, 105^{\circ} 18^{\prime}-105^{\circ} 25^{\prime} \mathrm{E}$ and of Tuyen Quang $21^{\circ} 49^{\prime} \mathrm{N}, 105^{\circ} 12^{\prime} \mathrm{E}^{\prime \prime}$ (Schileyko 2011), limiting the distribution of P. grandis.

The distribution of $P$. grandis seems to be more northern, close to the southern border of China when compared to $P$. heusii heusii. Hennemann \& Conle (2008: 205) examined 20 q $q, 21$ ô $\hat{0}$, and 1 egg

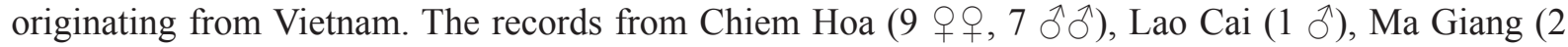
$\phi ㅇ)$ and the material collected by the second author all originate from this region. $6 q+q$ and $8 \delta^{\lambda} \delta^{\lambda}$ are labelled only "Tonkin".

The identity of $P$. grandis needs some clarification as the records from Tam Dao pertain to $P$. heusii heusii and one of the paratypes of $P$. fruhstorferi identified as P. grandis by Hennemann \& Conle (2008) is here attributed to $P$. heusii yentuensis subsp. nov. Unfortunately, the primary type of $P$. grandis does not bear an exact locality but only "North Tonkin"

Phryganistria heusii heusii (Hennemann \& Conle, 1997) Fig. 10C-D

Phobaeticus heusii Hennemann \& Conle, 1997: 505, figs 1-5.

Phryganistria heusii - Hennemann \& Conle 2008: 209.

Type material examined (on photographs)

Holotype ${ }^{\Uparrow}$ : N-Vietnam, Cuc Phuong, ex. Zucht (= rearing) P. Heusi 1996 (ZSMC, ex coll. FH, No. 0240-1)

Allotype,+ 1 egg: N-Vietnam, Cuc Phuong, ex. Zucht (= rearing) P. Heusi 1996 (ZSMC, ex coll. FH, No. 0240-2).

Additional material examined (22 $\hat{\rho} \hat{\jmath}, 6$ 우, 7 우 nymphs, 20 eggs)

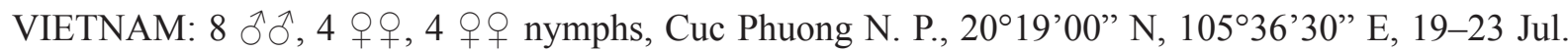

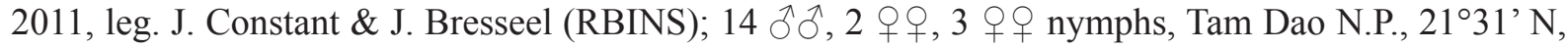
105³3’ E, 25-30 Jul. 2011, leg. J. Constant \& J. Bresseel (RBINS).

\section{Remarks}

Material from the type locality was collected and compared with specimens from other localities, which lead to the conclusion, that the species has a broader distribution than known to date. Hennemann \& Conle (2008: 205) examined one specimen from Tam Dao National Park, which was identified as Phryganistria grandis Rehn, 1906. The specimen bears the following data: 19: Vietnam: $55 \mathrm{~km}$ NNW Tam Dao, 26.VII.-10.VIII.1998, A. Napolov, BMNH(E) 2005-98, Phobaeticus grandis det. P. Brock 2005 (BMNH). Although identified as $P$. grandis, the specimen represents a female of $P$. heusii heusii (Hennemann \& Conle, 1997). Hennemann \& Conle (2008) did not have any males from Tam Dao NP to compare with material from the type locality and there is no doubt that specimens from Tam Dao NP are conspecific with $P$. heusii heusii.

Culture stock of this species was first collected by Peter Heusi (Switzerland) in 1996 from Cuc Phuong N.P. and is on the Phasmid Study Group culture-list as culture no. 277. Eggs collected by the authors in 2011 produced only males in the next generation. In captivity in Europe, Ph. heusii heusii can be successfully reared on a mixture of oak (Quercus spp., Fagaceae) and bramble (Rubus spp., Rosaceae) as alternative foodplants. Notes on breeding were provided by Bresseel (2007). 
BRESSEEL J. \& CONSTANT J., Pharnaciini from China and Vietnam (Phasmatodea: Phasmatidae)

\section{Distribution}

This species was described from Cuc Phuong National Park and is here also recorded from Tam Dao National Park (Fig. 12A).

\section{Phryganistria heusii yentuensis subsp. nov. urn:1sid:zoobank.org:act:CDA37092-5410-4797-A155-85327D3E2A3B}

Figs $8 \mathrm{~A}-\mathrm{N}, 11 \mathrm{~A}-\mathrm{B}$

\section{Diagnosis}

Males can be distinguished from all other members of the genus by the combination of the following characters: profemora black, meso- and metapleura with distinct triangular black marking and shape of the semitergites (Fig. 8K, M-N); females: tergites II-VII with a posteromedian granule and praeopercular organ of female wide and not strongly tapered (Fig. 8C).

\section{Etymology}

The subspecies name refers to its type locality: the Tay Yen Tu Nature Reserve.

\section{Type material}

\section{Holotype}

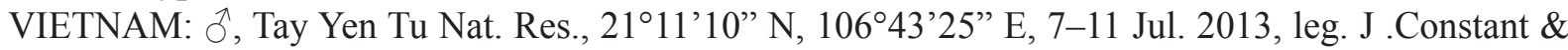
J. Bresseel, I.G. 32.454 (RBINS).

Paratypes $(10 \hat{\jmath} \hat{\partial}, 7 \uparrow q, 20$ eggs)

VIETNAM: Tay Yen Tu Nat. Res., 2111'10” N, 106²'25” E, 7-11 Jul. 2013, leg. J. Constant \& J. Bresseel, I.G. 32.454 (RBINS; 1 ô, 1 q: VNMN).

\section{Additional material examined}

VIETNAM: 1 गे, paralectotype of Phobaeticus fruhstorferi Brunner von Wattenwyl, 1907, Tonkin, Montes Mauson, April-May, 2-3000 m, H. Fruhstorfer (NMW). Specimen examined from detailed photographs in the Phasmida Species File (Brock 2014).

\section{Description}

The colouration is described from photographs of live specimens. Measurements, see Table 3.

Male (Fig. 8I-N)

BoDy. Large and relatively slender.

Colouration. Body surface smooth and glabrous, colouration characteristic. Overall colouration of body orange-brownish to light brown. Genae black. Distal portions of meso- and metapleura with distinct triangular black marking. Profemora basally as body, followed by large black portion, apex brown. Protibiae and tarsi blackish brown with a dark reddish hue. Meso- and metafemora coloured as body, ventral carinae with faint blue colouration. Armature black. Meso- and metatibiae coloured as femora except for blue markings.

HEAD. Smooth, 1.3x longer than wide, widest parts at eyes. Eyes relatively large and strongly projecting hemispherically. Small, shallow transverse sulcus between antennae. Vertex with faint median line, lateral edges of vertex with longitudinal depression, more distinct posteriorly. Antennae long and filiform, scapus and pedicellus coloured as head, all other antennomeres black. Scapus dorsoventrally flattened, pedicellus short and swollen, broader than following segments. 
Table 3. Measurements (mm) of Phryganistria heusii yentuensis subsp. nov.

\begin{tabular}{|lccc|}
\hline & Holotype $0^{\lambda}$ & Paratypes + + & Paratypes ô $^{\lambda}$ \\
\hline Body & 208.0 & $221.0-317.4$ & $177.0-245.0$ \\
Head & 8.4 & $11.1-14.1$ & $7.0-7.8$ \\
Pronotum & 6.4 & $7.7-9.8$ & $4.9-6.0$ \\
Mesonotum & 46.1 & $50.1-66.7^{*}$ & $41.7-45.6$ \\
Metanotum & 27.9 & $27.2-40.8$ & $25.5-27.8$ \\
Median segment & 7.6 & $8.1-11.1$ & $6.3-7.6$ \\
Profemora & 62.2 & $66.7-83.7$ & $62.1-65.0$ \\
Mesofemora & 48.7 & $54.4-64.9$ & $43.9-49.9$ \\
Metafemora & 58.9 & $59.6-75.5$ & $31.6-58.5$ \\
Protibiae & 89.3 & $91.5-112.6$ & $83.1-88.1$ \\
Mesotibiae & 52.7 & $58.2-71.4$ & $45.5-54.5$ \\
Metatibiae & 67.9 & $71.2-88.4$ & $67.0-70.8$ \\
\hline
\end{tabular}

$*$ mesonotum of all females deformed during drying process

Thorax. Pronotum shorter and narrower than head. Anterior margin concave. Pronotum gradually broadening until about $2 / 3$ of its length, remaining portion parallel-sided. Posterior margin rounded, with minute, granule-like elevation postero-medially. Transverse central depression and faint longitudinal depression, not reaching posterior margin. Mesonotum elongated and smooth, cylindrical in cross section. Metanotum as mesonotum, about $4 \mathrm{x}$ length of median segment.

ABDomen. Median segment trapezoidal and smooth, anterior margin indistinct. Terga II-VI becoming slightly longer and cylindrical in cross section. Segment VI about 1.3 to $1.4 \mathrm{x}$ as long as segment VII. Tergum VIII trapezoidal, about half of segment VII and wider posteriorly. Tergum IX shorter than VIII. Anal segment strongly tectiform basally, splitting into two semi-tergites. Semi-tergites elongated, relatively slender and tapered apically. Apices narrow and slightly rounded. Interior surface swollen basally and armed with numerous small, black, back-curving teeth. Outer surface setose. Cerci elongated, cylindrical in cross section, setose and incurving. Apices rounded, not reaching posterior margin of anal segment. Poculum strongly cup-shaped, with indistinct longitudinal carina in basal half, medially with V-like elevation, connecting distinct longitudinal carina in apical half with transverse ridges, roughly reaching apex of tergum IX.

Legs. Profemora longer than combined length of head, pro- and mesonotum, incurving basally and with anterodorsal carinae showing 12-19 black saw-like teeth. Protibiae carinate but unarmed, roughly $1.3 \mathrm{x}$ as long as profemora. Mesofemora swollen, about as wide as centre of mesonotum and roughly as long as mesonotum and pronotum combined. Outer ventral carinae armed with 10-15 black sawlike teeth, last teeth prominently enlarged, in some specimens last two teeth of carina enlarged. Medioventral carinae sometimes with few minute spines. Dorsal carinae unarmed or with 1-3 saw-like teeth. Mesotibiae slightly longer than mesofemora. Dorsal carinae unarmed or with few minute teeth. Outer ventral carinae strongly armed with saw-like teeth. Medioventral carinae with minute incurving spines starting at about $1 / 3$ of the base, spines more numerous towards apex. Metafemora and metatibiae as mesofemora and mesotibiae. All tarsomeres with distinct dorsal carina. Probasitarsus longer than 


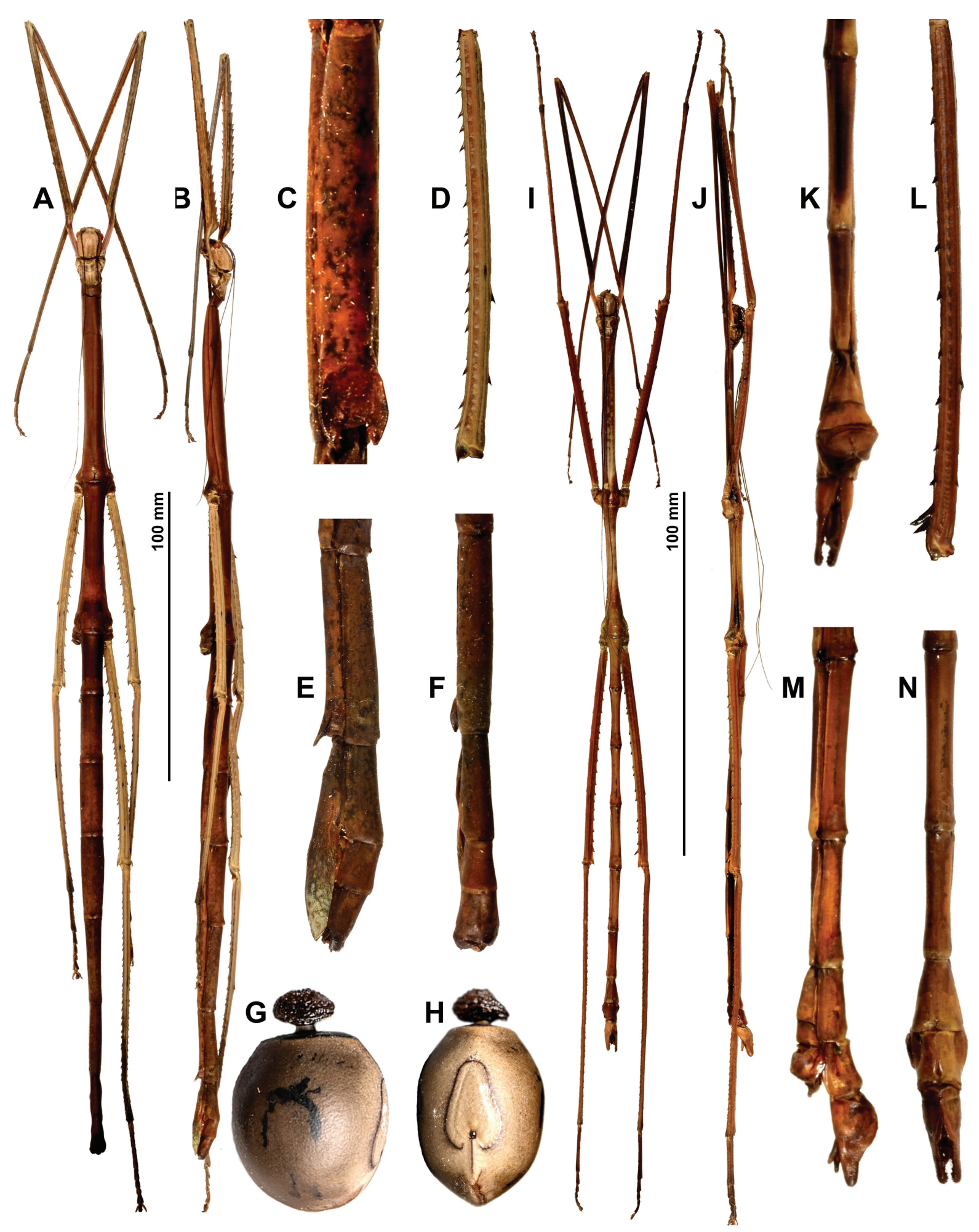

Fig. 8. Phryganistria heusii yentuensis subsp. nov. - A-F. ․ . A. Habitus, dorsal view. B. Habitus, lateral view. C. Sternum VII and praeopercular organ. D. Mesofemur, lateral view. E. Apex of abdomen, lateral view. F. Apex of abdomen, dorsal view. - G-H. Egg. G. Lateral view. H. Dorsal view. - I-N. $\widehat{\jmath}$. I. Habitus, dorsal view. J. Habitus, lateral view. K. Apex of abdomen, ventral view. L. Mesofemur, lateral view. M. Apex of abdomen, lateral view. N. Apex of abdomen, dorsal view. $\mathrm{C}-\mathrm{H}, \mathrm{K}-\mathrm{N}=$ not to scale. 
the following tarsomeres combined. Meso- and metabasitarsus about as long as following tarsomeres combined. Claws prominent.

Female (Fig 8A-F)

BoDy. Large to very large. Colouration of female green to brown. Basal curve of profemora pinkish.

HEAD. Oval, about 1.4-1.5x longer than wide, vertex rounded. Transverse, straight impression between bases of antennae. Eyes quite large, circular and convex. Antennae filiform with scapus dorsoventrally flattened, rectangular and slightly widening towards apex. Pedicellus short and cylindrical. Antennomere III about as long as pedicellus. Antennae projecting well over posterior margin of mesonotum.

Thorax. As in male.

Aвdomen. Median segment transverse, but longer than wide in the largest specimen. Segments II-VI slightly increasing in length, all having a posteromedian tubercle. Tergum VII shorter than VI and with posterolateral small, rounded lobe. Sternum VII with distinct praeopercular organ at posterior margin. Praeopercular organ formed by a pair of rounded lobe-like protuberances, rounded laterally and wrinkled ventrally; projecting over margin of sternum VIII. Tergum VIII distinctly narrower than previous one, laterally compressed and about half as long as V. IX roughly half as long as VIII. Anal segment slightly longer than IX, with faint median carina and almost triangular median incision at posterior margin. Posterolateral angles rounded apically. Supra-anal plate small, semi-circular and with distinct median carina, slightly surpassing anal segment. Cerci flattened, slender and blunt at apex, projecting over supra-anal plate. Gonapophyses elongated, up-curving and slightly projecting over apex of subgenital plate. Subgenital plate keeled, boat-shaped, surpassing apex of anal segment.

Legs. All moderately long and robust. Profemora longer than pro- and mesonotum combined; mesofemora as long as mesotibiae; metafemora reaching about halfway along abdominal segment V. Anterodorsal and posteroventral carinae of profemora armed with 13-19 prominent, triangular serrations. Posterodorsal carinae unarmed or armed with 1-3 minute spines. Other carinae unarmed. Protibiae carinate, roughly $1.3 \mathrm{x}$ as long as profemora, posteroventral carinae serrated with saw-like spines. Mesofemora swollen and roughly as long as mesotibiae. Outer ventral carinae armed with 13-18 saw-like teeth. Medioventral carina with 6-9 spines. Dorsal carinae with 1-4 saw-like teeth, being larger on anterodorsal carinae. Mesotibiae with strongly serrated ventral carinae. Anteroventral carinae with few small spines and enlarged saw-like spine at about $1 / 3$ of its length. Posterodorsal carinae with few minute spines. Metafemora and metatibiae as mesofemora and mesotibiae. All tarsomeres with distinct dorsal carina. Probasitarsus longer than following tarsomeres combined. Meso- and metabasitarsus with outer ventral carinae serrated basally, about as long as following tarsomeres combined. Claws prominent.

Egg (Fig. 8G-H)

Capsule oval in lateral aspect, rounded at polar area, slightly compressed laterally and oval in crosssection. Capsule with indistinct impression on polar area and ventral surface. Capsule surface smooth and slightly shining. General colouration of capsule and micropylar plate light brown to grey brown, sometimes with blakish areas. Operculum oval, brownish with black outer margin. Micropylar plate covering about half capsule length. Elongate, rounded towards anterior end and posteromedially with distinct gap. Posterolateral angles rounded. Outer margin dark. Micropylar cup small and dark brown, placed in posteromedial gap of plate. Median line distinctly projecting over posterior margin of plate. Capitulum enlarged, orange to reddish brown, irregularly conical and strongly wrinkled. Stalk obvious.

Measurements (mm): length including capitulum: 6.0, length: 5.0, width: 3.6, height: 4.0. 
BRESSEEL J. \& CONSTANT J., Pharnaciini from China and Vietnam (Phasmatodea: Phasmatidae)

\section{Differentiation}

Males share the black profemora and tibiae with the nominate form, but can easily be distinguished by the brown body colouration and meso- and metapleura with distinct triangular black marking. Apices of praeopercular organ of female wider but not as strongly tapered when compared with Ph. heusii heusii. Micropylar plate of egg rounded anteriorly (tapered in nominal form) and capitulum strongly enlarged.

\section{Remarks}

Hennemann \& Conle (2008: 204) stated that the three male paralectotypes of Phryganistria fruhstorferi (Brunner von Wattenwyl, 1907) in NMW represent males of Phryganistria grandis Rehn, 1906. However, one of these paralectotypes has turned out to be a Phryganistria heusii yentuensis subsp. nov. The male originates from Mount Mauson (misspelled on the original label as 'Montes Mahokon').

Hennemann \& Conle (2008) examined a large amount of non-type material of Phryganistria grandis, but only this specimen originates from Mount Mauson.

Eggs of this subspecies have been collected from Tay Yen Tu Nature Reserve and it is currently reared by Dr. Bruno Kneubühler (Switzerland) with bramble (Rubus spp., Rosaceae) as alternative foodplant.

P. heusii yentuensis subsp. nov. is the second longest insect species known to date: a female with a 320.0 $\mathrm{mm}$ body length, $540.0 \mathrm{~mm}$ with anterior legs spread (Fig. 11A-B) was captured and measured in the field.

\section{Distribution (Fig. 12C)}

This subspecies is currently recorded from Tay Yen Tu Nature Reserve located in Luc Nam and Son Dong Districts, Bac Giang Province, about 150 kilometers ENE of Hanoi. Another specimen is also reported from northeast Vietnam: Mount Mauson, $30 \mathrm{~km}$ E of Lang Son city.

Phobaeticus Brunner von Wattenwyl, 1907

Phobaeticus Brunner von Wattenwyl, 1907: 183.

Type species

Phobaeticus sobrinus Brunner von Wattenwyl, 1907: 184, pl. 7: 1a-b, by subsequent designation of Brock 1996: 28.

\section{Distribution}

India, Sri Lanka, Bangladesh, Myanmar, Laos, Thailand, Peninsular Malaysia, Singapore, Sumatra, Banka Island, Borneo, Palawan, Philippines and Vietnam (new record).

Phobaeticus trui sp. nov. urn:1sid:zoobank.org:act:170DDF9E-44F6-452E-B6CC-740267ABF905

Figs $9 \mathrm{~A}-\mathrm{N}, 11 \mathrm{C}-\mathrm{D}$

\section{Diagnosis}

Females can be distinguished from all other members of the genus by the shape of the praeopercular organ (Fig. 9C) Males can be distinguished by the length of the alae and the shape of the semitergites. (Fig. 9G-L). 
Table 4. Measurements (mm) of Phobaeticus trui sp. nov.

\begin{tabular}{|lccc|}
\hline & Holotype $\tilde{\delta}^{\lambda}$ & Paratype $q$ & Paratype $\oint^{\uparrow}$ \\
\hline Body & 174.0 & $243.0-266.0$ & $171.0-192.0$ \\
Head & 7.5 & $14.2-15.2$ & $7.9-8.2$ \\
Pronotum & 4.6 & $9.2-10.8$ & $5.3-5.7$ \\
Mesonotum & 41.2 & $49.0-53.7$ & $42.8-46.6$ \\
Metanotum & covered by wings & $18.8-19.0$ & 21.0 \\
Median segment & covered by wings & $13.5-15.0$ & 4.1 \\
Profemora & 57.8 & $58.8-66.1$ & $64.8-65.4$ \\
Mesofemora & 48.6 & $47.6-54.0$ & $47.8-52.6$ \\
Metafemora & 56.3 & $44.2-62.3$ & $55.1-61.9$ \\
Protibiae & 75.1 & $68.9-73.2$ & $76.9-83.7$ \\
Mesotibiae & 48.16 & $46.7-48.4$ & $47.0-52.5$ \\
Metatibiae & 60.1 & $57.4-58.8$ & $59.9-67.8$ \\
Tegmina & 13.8 & $/$ & $13.7-14.4$ \\
Alae & 25.2 & $/$ & $24.0-25.8$ \\
\hline
\end{tabular}

\section{Etymology}

The species is dedicated to our Vietnamese colleague Vu Tru Hoang (IEBR), better known as "Mr Tru".

\section{Type material}

\section{Holotype}

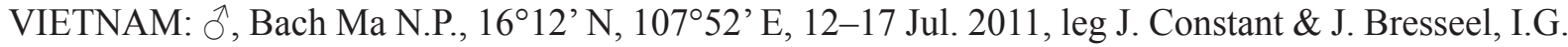
31.933 (RBINS).

Paratypes $(3 \hat{\jmath} \hat{0}, 2$ 우, 3 우 nymphs in penultimate stadium)

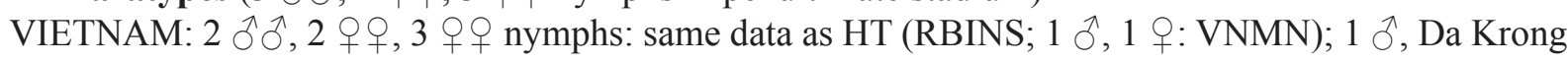
Nat. R., Quang Tri Prov., 16³7’ N, 106² 47’ E, 5-10 Jul. 2011, leg. J. Constant \& J. Bresseel, I.G. 31.933 (RBINS).

\section{Differentiation}

Similar to Phobaeticus ingens (Redtenbacher, 1908) from Myanmar and India, P. rex (Günther, 1928) from Peninsular Malaysia and Sumatra, and also P. hypharpax (Westwood, 1859) and P. lobulatus (Carl, 1913), both from Sri Lanka.

Males can be easily distinguished from $P$. ingens and $P$. hypharpax by their considerably shorter alae, which only reach the posterior margin of abdominal segment II, while these project beyond the posterior margin of abdominal segment IV in P. ingens and P. hypharpax. Males of $P$. rex and P. lobulatus are unknown.

Females can be distinguished from all closely related species by the strongly developed bilobed praeopercular organ. Furthermore it can be differentiated from P. rex, P. hypharpax and P. lobulatus 


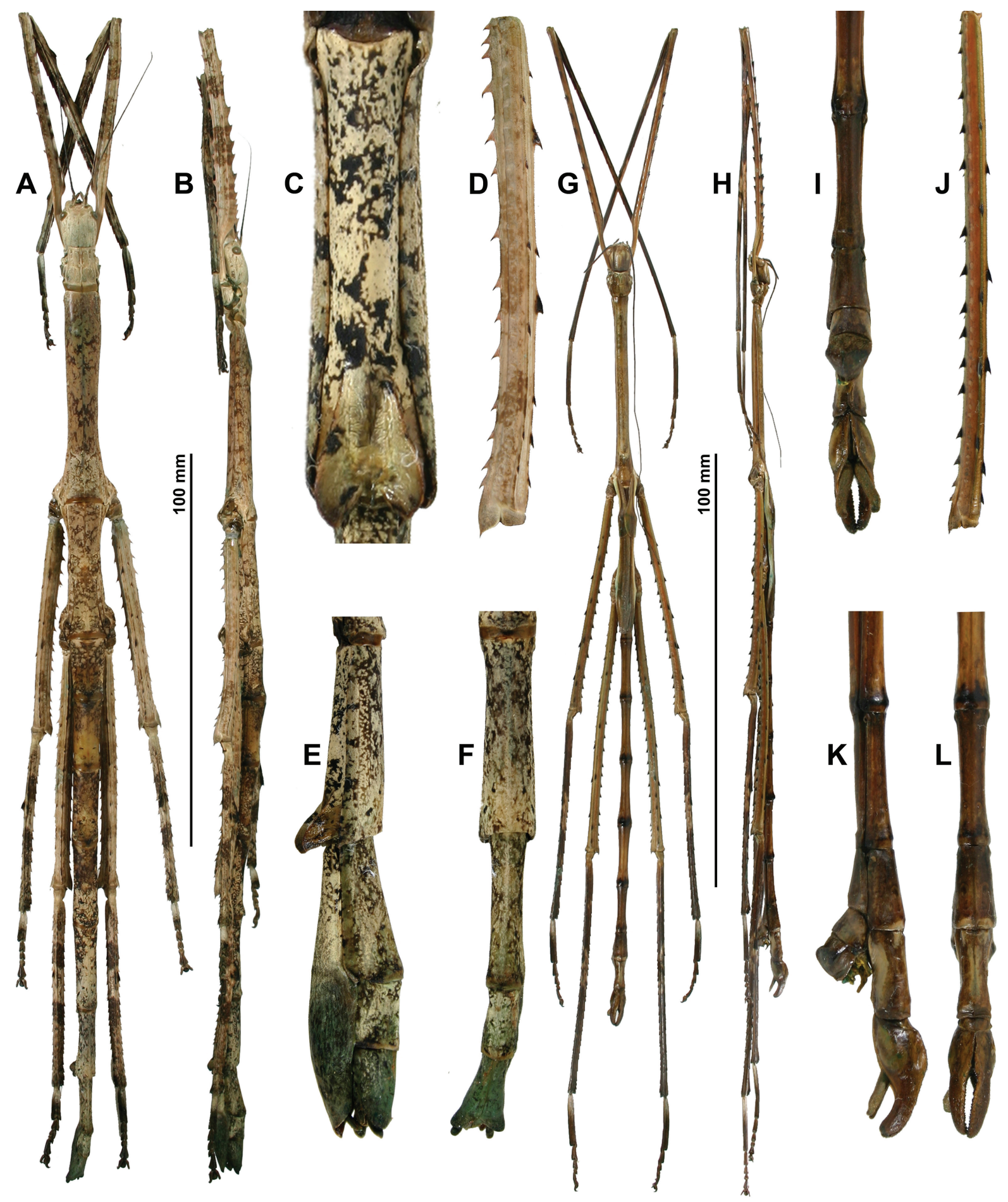

Fig. 9. Phobaeticus trui sp. nov. - A-F. . . A. Habitus, dorsal view. B. Habitus, lateral view. C. Sternum VII and praeopercular organ. D. Mesofemur, lateral view. E. Apex of abdomen, lateral view. F. Apex of abdomen, dorsal view. - G- L. J. G. Habitus, dorsal view. H. Habitus, lateral view. I. Apex of abdomen, ventral view. J. Mesofemur, lateral view. K. Apex of abdomen, lateral view. L. Apex of abdomen, dorsal view. $\mathrm{C}-\mathrm{F}, \mathrm{I}-\mathrm{L}=$ not to scale. 

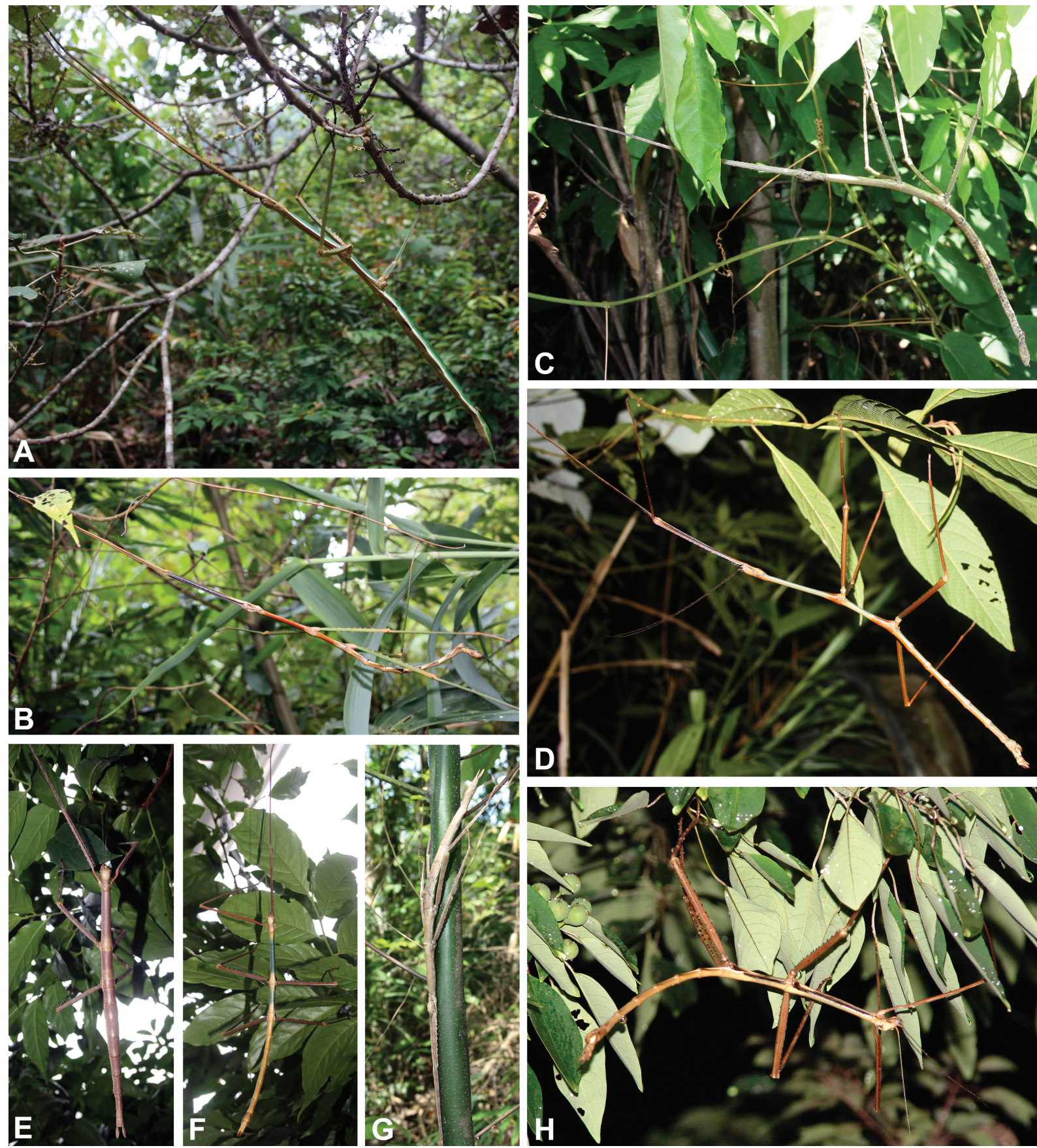

Fig. 10. Phryganistria spp., photographs in natura by the authors. - A-B. P. bachmaensis. A. $\$$, Bach

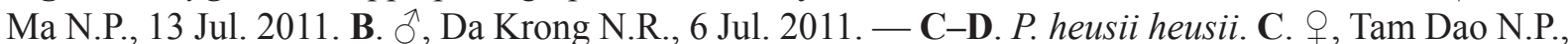

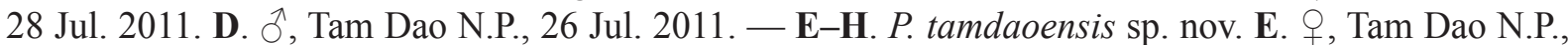
29 Jul. 2011. F. O̊, Tam Dao N.P., 29 Jul. 2011. G. ㅇ, Da Krong N.R., 6 Jul. 2011. H. đૈ, Tay Yen Tu N.R., 7 Jul. 2013. 
BRESSEEL J. \& CONSTANT J., Pharnaciini from China and Vietnam (Phasmatodea: Phasmatidae)

by the small lateral lobes of abdominal tergum VII. From $P$. ingens they can be differentiated by the relatively longer median segment, which is more than $2 / 3$ the length of metanotum.

\section{Description}

The colouration is described from photographs of live specimens. Measurements, see Table 4.

Male (Fig. 9G-L)

BoDy. Large (body length 172.4-190.4 mm) with short alae (23.4-25.8 mm).
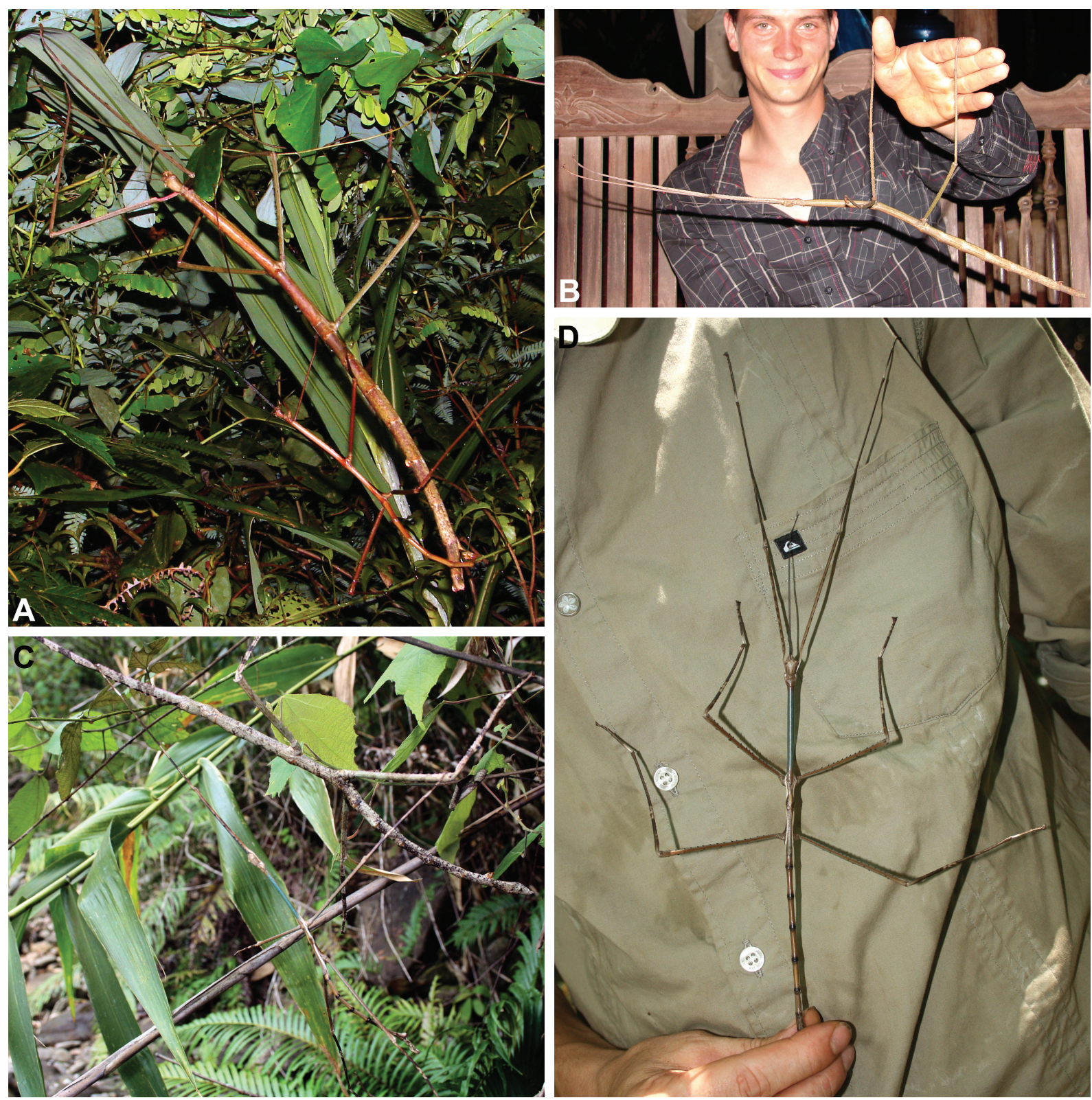

Fig. 11. Photographs in natura by the authors. - A-B. Phryganistria heusii yentuensis subsp. nov. A. Mating pair. B. The first author with the $31.7 \mathrm{~cm}$ long , Tay Yen Tu N.R., 9 Jul. 2013. - C-D.

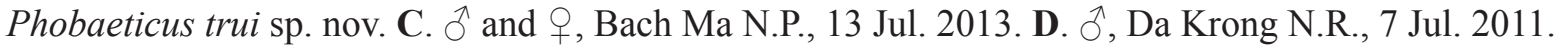


Colouration. Head, pronotum, margins of mesonotum and metanotum pale brown, mesonotum except margins greenish blue. Abdominal segments II-VII pale brown, with black transverse band posteriorly. Segment VIII pale brown and segments IX-X pale brown with some whitish markings. Tegmina and costal region of alae pale brown with central portion darker brown and with anterior margin white. Anal region transparent grey with brown veins. Profemora with carinae black and paler markings in between. Meso- and metafemora with carinae greenish blue and black saw-like teeth, other areas of meso- and metafemora brownish pink. Tibiae and tarsomeres dark brown with several distinct pale transverse bands.

HEAD. Elongate, oval, about one third longer than wide, slightly narrowing basally and with faint impressed median line and two faint impressed lines on each side of head. Posterior portion with two longitudinal lateral impressions at each side of coronal-line. Slightly raised, smooth, C-shaped area between eyes. Eyes very prominent, strongly convex and projecting hemispherically. Antennae almost reaching median segment. Scapus dorsoventrally flattened with longitudinal impression ventrally. Pedicellus short, cylindrical. Length of antennomeres increasing towards apex of antennae.

THORAX. Pronotum distinctly shorter and narrower than head, $1.3 x$ longer than wide, posterior margin broader than anterior one. Anterior margin raised, followed by transverse depression and short longitudinal indentation turning into a longitudinal median line. Median transverse depression distinct, not reaching lateral margins of segment. Mesothorax smooth and elongated, $3 \mathrm{x}$ to almost $3.5 \mathrm{x}$ longer than head and pronotum combined. Tegmina projecting over anterior margin of metanotum, elongated, narrowed basally. Alae reaching about halfway along abdominal tergum II.

АвDOMEN. Segments II-V slightly increasing in length and roughly of equal width, all slightly constricted medially. Tergum V with distinct hump posteromedially; VI and VII slightly shorter than previous; VI slightly broadened posteriorly; VIII $2 / 3$ as long as VII and strongly broadened posteriorly; IX slightly longer than VIII, but distinctly narrower, broadened anteriorly and constricted medially. Anal segment longer than IX, laterally compressed and tectiform. Semi-tergites elongated, tapered but not pointy and gently down-curving. Interior surface densely covered with minute black teeth (thorn-pads). Cerci elongated, cylindrical in cross section, in-curving and tapered apically. Poculum reaching about halfway along tergum IX, strongly convex and cup-like.

LEGS. All very elongated, profemora longer and mesofemora almost as long as head, pro- and mesothorax combined, metafemora reaching about halfway along abdominal segment VI and metatibiae surpassing apex of abdomen. Anterodorsal carina of profemora with 7-15 prominent saw-like teeth. Posterodorsal carina sometimes with 1-2 small, triangular teeth. Posterodorsal carina smooth. Posteroventral carina with 5-12 small, pointed teeth. Anterodorsal carina of protibiae sometimes with small triangular lobe, otherwise unarmed. All carinae of meso- and metafemora prominent, armed with several black small, saw-like teeth. Ventral carinae of meso- and metatibiae with minute serrations all long. Anterodorsal carina serrated and with larger, triangular pre-medial teeth. Posterodorsal carina also with small serrations. Basitarsi with uniformly raised dorsal carina, longer than remaining segments combined. Dorsal carina of all tarsi resulting in a posteromedian lobe, projecting over following tarsus. Claws prominent.

Female (Fig. 9A-F)

BoDy. Very long (body length 243-266 mm), broad and sturdy species.

Colouration. General colour of body and legs mid to dark brown, with numerous irregular paler and darker markings and spots. Forelegs and meso- and metatibiae with more or less distinct dark transverse bands. Armature of legs reddish brown to black. Eyes pale brown. Antennae dark greyish brown. 
BRESSEEL J. \& CONSTANT J., Pharnaciini from China and Vietnam (Phasmatodea: Phasmatidae)
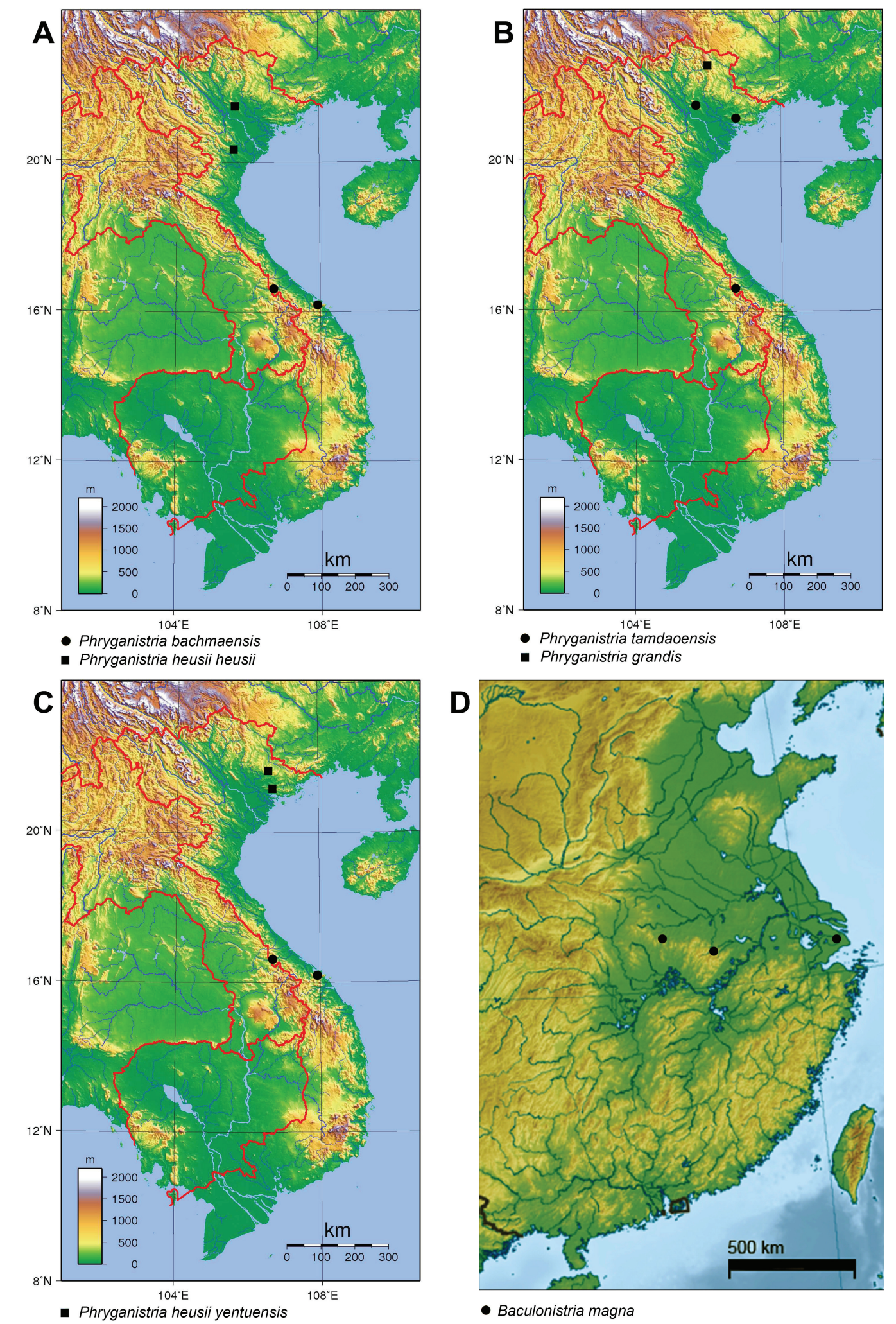

Fig. 12. Distribution maps. A. Phryganistria bachmaensis (Ta \& Hoang, 2004) comb. nov. and $P$. heusii heusii (Hennemann \& Conle, 1997). B. P. tamdaoensis sp. nov. and P. grandis Rehn, 1906. C. Phryganistria heusii yentuensis subsp. nov. and Phobaeticus trui sp. nov. D. Baculonistria magna (Brunner von Wattenwyl, 1907) comb. nov. 
HEAD. Elongate, oval, 1.6x longer than wide, slightly narrowing basally; vertex smooth and gently convex. Two transverse median impressions, one between antennae and one between eyes. Eyes large, strongly convex and projecting laterally. Antennae filiform, rather short, not reaching apex of profemora. Scapus dorsoventrally flattened. Pedicellus cylindrical, shorter than first antennomere.

Thorax. Pronotum shorter and narrower than head, about 1.3x longer than wide, posterior margin broader than anterior margin, slightly constricted centrally. Anterior margin with three small, holelike impressions, one central and two antero-lateral. Antero-median impression followed by median longitudinal line. Median transverse depression distinct, not reaching lateral margins. Mesothorax parallel-sided except for gradually widening posterior part, about 3.5x longer than head. Mesonotum with very faint longitudinal median line. Metanotum slightly more than $1 / 3$ as long as mesonotum. Small, yet distinct posteromedian granule. Vestigial wings visible as small scales.

ABDomen. Median segment slightly shorter than metanotum. Segment II about as long as median segment. Terga III-V slightly increasing in length; V and VI of same length, with indistinct posteromedian hump; VII about as long as IV. Praeopercular organ distinct, represented by a pair of large lobes at posterior margin of sternum VII. Ventral view of praeopercular organ inverted heart-shaped about $1 / 3$ the length of sternum VII. Tergum VIII distinctly shorter than previous and strongly convex; IX about half as long as VIII and strongly convex. Anal segment 1.5x length of IX, with fine median carina and widely triangular indentation at posterior margin, outer angles triangular. Supra-anal plate small, strongly keeled and rounded, not projecting beyond outer angles of anal segment. Cerci small, slightly flattened dorso-ventrally, oval in cross-section, finely setose and slightly exceeding anal segment. Gonapophyses filiform, up-curving but not reaching apex of anal segment. Subgenital plate longitudinally keeled, boatshaped and reaching posterior margin of anal segment.

Legs. All long and broad, profemora slightly longer than combined length of pro- and mesonotum; mesofemora about as long as mesothorax; metafemora reaching over halfway the abdominal segment $\mathrm{V}$ and metatarsi nearly reaching apex of abdomen. Anterodorsal carina of profemora with 9-13 prominent, broad and undulate serrations. Posterodorsal carina sometimes with 4-8 small, triangular teeth. Posteroventral carina with 10-16 broad and undulate serrations. Anteroventral carina and medioventral carina strongly raised. Anterodorsal carina of protibiae raised, with 3-7 broad, triangular, lobe-like serrations. Posterodorsal carina with some small acute spines. Posterodorsal carina of mesofemora armed with 5-8 small saw-like spines; anterodorsal carina armed with 7-10 saw- to more prominent wave-shaped spines. Dorsal carinae of metafemora with 6-7 small saw-like spines. Medioventral of meso- and metafemora with 4-8 spines. Ventral carinae with 14-20 spine-like serrations. Ventral carinae of meso- and metatibiae serrated with small teeth. Dorsal carinae serrated with large to very large, roundly triangular pre-medial lobe; lobe more prominent on anterodorsal carina. Anterodorsal carina forming rounded, dentate lobe at apex of tibia. Probasitarsus with uniformly raised dorsal carina, about as long as remaining segments combined. Second tarsomere with dorsal carina raised and rounded. Meso- and metabasitarsus almost as long as remaining tarsomeres combined except claw and apically with dentate dorsal carina, gradually increasing in height.

Egg

Unknown.

Distribution (Fig. 12 C)

This species is known from central Vietnam: Bach Ma National Park and Da Krong Nature Reserve. 
BRESSEEL J. \& CONSTANT J., Pharnaciini from China and Vietnam (Phasmatodea: Phasmatidae)

Tirachoidea Brunner v. Wattenwyl, 1893

Tirachoidea Brunner v. Wattenwyl, 1893: 83.

Type species

Phibalosoma cantori Westwood, 1859: 74, pl. 37: 1, 1a-b \& pl. 38: 1, 1a-b, by subsequent designation of Kirby 1904a: 359.

\section{Distribution}

India, Bangladesh, Thailand, Myanmar, Vietnam, South China, Malaysia and Indonesia.

\section{Species recorded from Vietnam}

1. Pharnacia jianfenglingensis Bi, 1994: 10. [S-China (Hainan \& Yunnan) and North Vietnam (Cuc Phuong \& Cat Bat N.P.)]

2. Tirachoidea siamensis Henneman \& Conle, 2008: 244. [Thailand \& S-Vietnam (Cat Tien N.P. and Dong Nai Biosphere Reserve)]

Tirachoidea jianfenglingensis $(\mathrm{Bi}, 1994)$

Pharnacia jianfenglingensis Bi, 1994: 10.

Tirachoidea jianfenglingesis - Hennemann \& Conle, 2008: 240.

\section{Material examined}

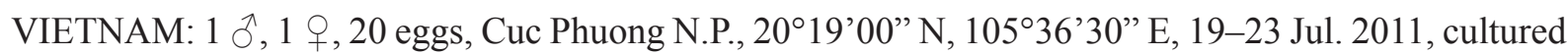
at Bristol Zoo via Mark Bushell (RBINS); 1 추, 2 우우 (collected as nymphs and captive reared), Cat Ba N.P., $20^{\circ} 48^{\prime} 00^{\prime \prime}$ N, 10700’20” E, 12-16 Jul. 2013, night collecting, leg. J. Constant \& J. Bresseel, I.G. 32.454 (RBINS).

\section{Remarks}

The species was originally described from Jianfengling National Forest Park in Hainan province, South China (Bi 1994). Hennemann \& Conle (2008: 240) recorded this species from Cuc Phuong National Park and Than Moi in Vietnam, and Jinping County, Yunnan Province (900-1000 m) in Southern China. Recently Ho (2013) recorded the species from Hong Kong. The authors collected four nymphs of this species in Cat Ba National Park, Vietnam. One male and one female were reared to adulthood on a mixture of oak (Quercus spp., Fagaceae) and bramble (Rubus spp., Rosaceae). These records show that the species has a wide distribution range, which can also be observed in several other representatives of the genus Tirachoidea: e.g., T. biceps (Redtenbacher, 1908) from Java, Sumatra, Lombok and Peninsular Malaysia, and T. cantori (Westwood, 1859) recorded from Peninsular Malaysia, Thailand and South Myanmar.

Tirachoidea siamensis Hennemann \& Conle, 2008

Tirachoidea siamensis Hennemann \& Conle, 2008: 244 (type locality: North Thailand)

\section{Material examined}

VIETNAM: $1 \hat{\delta}, 3$ 우 (collected as nymphs and reared to adulthood in captivity), 120 eggs: Cat Tien N. P., 1126' N, 107²6’ E, 6-16 Jul. 2012, leg. J. Constant \& J. Bresseel, I.G. 32.161 (RBINS). 


\section{Comments}

In the original description, Hennemann \& Conle (2008: 144) excluded the material from Southern Vietnam from the type series because they estimated that the location of the specimen was doubtful. Four nymphs were collected by the authors in Cat Tien National Park on Lagerstroemia sp. (Lythraceae). In Europe they accepted oak (Quercus spp., Fagaceae) and bramble (Rubus spp., Rosaceae). All specimens reached adulthood and clearly represent Tirachoidea siamensis Hennemann \& Conle, 2008, which confirms the presence of this species in Southern Vietnam. One small nymph was encountered in Dong Nai Biosphere Reserve but was not collected.

\section{Discussion}

The Phasmatodea of Vietnam remain poorly studied. Although some 70 species have been described (e.g., Kirby 1904; Brunner von Wattenwyl 1907; Redtenbacher 1908; Carl 1913), much work needs to be done describing new species and genera, in addition to redescribing and clarifying the status of existing taxa. Many genera are currently heterogeneous and prior to the description of new species, genera should be well defined and many species have to be transferred to different and even new genera.

The authors have built a large reference collection with thousands of specimens and hundreds of species. A catalogue of all species described from or present in Vietnam is in progress.

The discovery of several new giant species provides some evidence that there is a large number of new Vietnamese species still in need of description.

The Pharnaciini was recently revised by Hennemann \& Conle (2008) and therefore the genera included are well defined and new species could be incorporated.

The types of the two Chinese species of Phryganistria could not be traced in IZCAS nor could any other types of species described by Chen \& He (pers. comm. Rong Rong Wang, IZCAS). At the moment there are clearly several species currently attributed to the genus Ramulus Saussure, 1862 that should be transferred to Baculonistria Hennemann \& Conle, 2008. Examination of the type specimens is necessary to compare and differentiate with the species currently attributed to Baculonistria.

\section{Acknowledgements}

We thank Dr. Hong Thai Pham (VNMN), Mr Hoang Vu Tru, Mr Thieu Du Tran, Mrs Le My Hahn (IEBR), and Mr Pol Limbourg (RBINS) for all their help and friendship during collecting trips, Dr Bruno Kneubühler (Switzerland) for his excellent pictures and for all his help in breeding the species we brought back from the field, and Mr Ludovic Nicolas for helping mount numerous specimens we brought back from the field. Emmanuel Delfosse and Harald Bruckner are thanked for their cooperation and for detailed pictures of the types in MNHN and NHMW, respectively. Mark Bushell (Bristol Zoo, U.K.) donated material of Tirachoidea jianfenglingensis and Dr Rong Rong Wang provided information about the IZCAS collection. We thank Dr Vladimir Gnezdilov for translating the labels written in Russian. The authors' collecting trips were supported through grants issued by the capacity building Programme of the Belgian Global Taxonomic Initiative National Focal Point that runs with financial support from the Belgian Directorate-General for Development Cooperation. Dr Patrick Grootaert, Dr Yves Samyn and Dr Marie-Lucie Susini (RBINS) are also thanked for their permanent support to our projects in Vietnam. Paul Brock (United Kingdom) is thanked for proofreading the manuscript.

\section{References}

Bragg P. 2008. Phobaeticus chani. In: Hennemann F.H. \& Conle O.V., Revision of Oriental Phasmatodea: The tribe Pharnaciini Günther, 1953, including the description of the world's longest insect, and a 
BRESSEEL J. \& CONSTANT J., Pharnaciini from China and Vietnam (Phasmatodea: Phasmatidae)

survey of the family Phasmatidae Gray, 1835 with keys to the subfamilies and tribes (Phasmatodea: 'Anareolatae': Phasmatidae). Zootaxa 1906: 1-316.

Bi D. 1994. A new species of the genus Pharnacia Stål from Hainan Province of China (Phasmatidae: Phasmatinae). Entomological Journal of East China 3(1): 10-12.

Bi D. \& Wang Z. 1998. Three new species of Phasmatodea from Henan Province (Phasmatodea: Phasmatidae: Heteronemiidae). In: Chen X. \& Shi Z. (eds), Insects of the Funju Mountains Region: 9-13. China Agricultural Scientech Press, Beijing.

Bradler S. 2001. Die australischen Stabschrecken - die "Beuteltiere" unter den Phasmatodea? Verhandlungen der Westdeutschen Entomologischen Tagung 2000, Löbbecke-Museum Düsseldorf: 179-184.

Bragg P.E. 1995. A new species of Nearchus (Insecta: Phasmida: Phasmatidae) from Borneo and the description of the male of $N$. redtenbacheri. Zoologische Mededelingen 69(21): 273-279. http://www. repository.naturalis.nl/document/149609

Bresseel J. 2007. Species report no 6: PSG 277 Phobaeticus heusii (Hennemann \& Conle, 1997), een mooie grote wandelende tak uit Vietnam. Phasma 17(64): 8-9.

Brock P.D. 1996. Changes of taxonomy in giant stick-insects. Phasmid Studies 5(1): 25-31. http:// phasmid-study-group.org/sites/phasmid-study-group.org/files/PS5.pdf

Brock P.D. 1998. A new species of Phobaeticus Brunner von Wattenwyl, from the Philippines (Phasmatidae). Phasmid Studies 6(2): 43-45. http://phasmid-study-group.org/sites/phasmid-studygroup.org/files/Phasmid\%20Studies\%206\%2812\%29.pdf

Brock P.D. 1998. Catalogue of type-specimens of Stick- and Leaf-Insects in the Naturhistorisches Museum Wien (Insecta: Phasmida). Kataloge der wissenschaftlichen Sammlungen des Naturhistorischen Museums in Wien 13(5): 1-72. http://www.landesmuseum.at/pdf_frei_remote/kat-nhmw_13 0003-0072. $\underline{\mathrm{pdf}}$

Brock P.D. \& Delfosse E. 2005. A list of Pantel's phasmid type material in the Muséum National d'Histoire Naturelle, Paris (Phasmida). Revue française d'Entomologie (N.S.) 27(2): 49-56.

Brock P.D. 2007. The types of Phasmida in the Zoological Institute, Russian Academy of Sciences, St. Petersburg (ZMAS). Zootaxa 1398: 45-56.

Brock P.D. 2014. Phasmida Species File Online. Version 5.0/5.0, available from http://Phasmida. SpeciesFile.org (Accessed 16 Feb. 2014).

Brunner v. Wattenwyl K. 1893. Révision du système des orthoptères et description des espèces rapporteés par M. Leonardo Fea de Birmanie. Annali del Museo Civico di storia naturale Giacomo Doria, Genova (2) 13(33): 76-101 \& 217-219. http://biodiversitylibrary.org/page/29845250

Brunner v. Wattenwyl, K. 1907. Die Insektenfamilie der Phasmiden. II. Phasmidae Anareolatae (Clitumnini, Lonchodini, Bacunculini). Verlag W. Engelmann, Leipzig.

Carl J. 1913. Phasmides nouveaux ou peu connus du Muséum de Genève. Revue Suisse de Zoologie 21(1): 1-55. http://biodiversitylibrary.org/page/10712538

Chen S.C. \& He Y. 2008. Phasmatodea of China. China Forestry Publishing House, Beijing.

Hennemann F. H. \& Conle O.V. 1997b. Eine bemerkenswerte, neue Riesenstabschrecke aus Vietnam Phobaeticus heusii sp. nov. Entomologische Zeitschrift 107(12): 504-509. 
Hennemann F.H., Conle O.C. \& Zhang W.W. 2008. Catalogue of the Stick and Leaf-insects (Phasmatodea) of China, with a faunistic analysis, review of recent ecological and biological studies and bibliography (Insecta: Orthoptera: Phasmatodea). Zootaxa 1735: 1-77.

Hennemann F.H. \& Conle O.V. 2008. Revision of Oriental Phasmatodea: The tribe Pharnaciini Günther, 1953, including the description of the world's longest insect, and a survey of the family Phasmatidae Gray, 1835 with keys to the subfamilies and tribes (Phasmatodea: "Anareolatae": Phasmatidae). Zootaxa 1906:1-316.

Ho G.W.C. 2013. Stick Insects of Hong Kong. Insect Fauna of Hong Kong. Hong Kong Entomological Society, Hong Kong.

Kirby W.F. 1904. A Synonymic Catalague of Orthoptera. 1. Orthoptera Euplexoptera, Cursoria et Gressoria. (Forficulidae, Hemimeridae, Blattidae, Mantidae, Phasmidae). British Museum, London. http://biodiversitylibrary.org/page/6196392

Otte D. \& Brock P. 2005. Phasmid Species File. Catalog of Stick and Leaf Insects of the World, 2nd Edition. The Insect Diversity Association and the Academy of Natural Sciences, Philadelphia, CafePress. com.

Redtenbacher J. 1908. Die Insektenfamilie der Phasmiden. III. Phasmidae, Anareolatae (Phibalosomini, Acrophyllini, Necrosciini). Verlag W. Engelmann, Leipzig. https:/ia600401.us.archive.org/34/items/ DieInsektenfamilieDerPhasmidenVol.1/DieInsektenfamilieDerPhasmidenVol.1.1906.pdf

Schileyko A.A. 2011. Check-list of land pulmonate molluscs of Vietnam (Gastropoda: Stylommatophora). Ruthenica 21(1): 1-68. http://www.ruthenica.com/documents/vol21_Schileyko 1-68.pdf

Ta H.T. \& Hoang V.T. 2004. A new species of Nearchus Redtenbacher (Phasmatodea: Phasmatidae) from Vietnam. Tap chi SINH HOC 26(3A): 15-18 (in Vietnamese with English summary).

Thinh T.H. \& Tru H.V. 2004. See Ta H.T. \& Hoang V.T. 2004.

Zompro O. 2005. The first record of Korinnis Günther, 1932 from Thailand and from the Philippines, and the description of a new species of Pharnacia Stål, 1877 (Insecta: Phasmatodea). Entomologische Zeitschrift 115(2): 71-74.

Manuscript received: 23 June 2014

Manuscript accepted: 13 November 2014

Published on: 27 November 2014

Topic editor: Koen Martens

Desk editor: Kristiaan Hoedemakers

Printed versions of all papers are also deposited in the libraries of the institutes that are members of the EJT consortium: Muséum National d'Histoire Naturelle, Paris, France; Botanic Garden Meise, Belgium; Royal Museum for central Africa, Tervuren, Belgium; Natural History Museum, London, United Kingdom; Royal Belgian Institute of Natural Sciences, Brussels, Belgium; Natural History Museum of Denmark, Copenhagen, Denmark. 